\title{
Measuring fish condition: an evaluation of new and old metrics for three species with contrasting life histories
}

\begin{tabular}{|r|l|}
\hline Journal: & Canadian Journal of Fisheries and Aquatic Sciences \\
\hline Manuscript ID & cjfas-2018-0076.R1 \\
\hline Manuscript Type: & Article \\
\hline $\begin{array}{r}\text { Date Submitted by the } \\
\text { Author: }\end{array}$ & 02-Jul-2018 \\
\hline $\begin{array}{r}\text { Complete List of Authors: } \\
\text { Keyword: }\end{array}$ & $\begin{array}{l}\text { Wuenschel, Mark; National Marine Fisheries Service - NOAA, } \\
\text { McElroy, W. ; Integrated Statistics Inc. } \\
\text { Oliveira, Kenneth; UMASS Dartmouth, Department of Biology } \\
\text { McBride, Richard; National Marine Fisheries Service - NOAA }\end{array}$ \\
\hline $\begin{array}{r}\text { PHYRIOLOGY < General, LIPIDS < General, BIOMETRICS < } \\
\text { General }\end{array}$ \\
\hline $\begin{array}{r}\text { Is the invited manuscript } \\
\text { for consideration in a } \\
\text { Special Issue? : }\end{array}$ & Not applicable (regular submission) \\
\hline & \\
\hline
\end{tabular}



Measuring fish condition: an evaluation of new and old metrics for three species with contrasting life histories

Mark J. Wuenschel ${ }^{1 *}$, W. David McElroy ${ }^{2}$, Kenneth Oliveira ${ }^{3}$, and Richard S. McBride ${ }^{1}$

$4 \quad{ }^{1}$ Northeast Fisheries Science Center, National Marine Fisheries Service, National Oceanic and 5 Atmospheric Administration Woods Hole, MA 02543, USA. ${ }^{2}$ Integrated Statistics Inc. Woods

6 Hole, MA 02543, USA. Under contract to: Northeast Fisheries Science Center, National Marine

7 Fisheries Service, National Oceanic and Atmospheric Administration, Woods Hole, MA 02543,

8 USA ${ }^{3}$ Department of Biology, University of Massachusetts Dartmouth.

9 Mark.Wuenschel@noaa.gov, Dave.McElroy@noaa.gov, Koliveira@umassd.edu,

10 Richard.McBride@noaa.gov

11 Corresponding author: Mark J. Wuenschel, e-mail Mark.Wuenschel@,noaa.gov. Northeast

12 Fisheries Science Center, National Marine Fisheries Service, National Oceanic and Atmospheric 13 Administration, 166 Water Street, Woods Hole, MA 02543, USA. Phone (508)-495-2276, Fax $14 \quad(508)-495-2258$.

16 Abstract

17 Measuring fish condition should link ecosystem drivers with population dynamics, if the 18 underlying physiological basis for variations in condition indices are understood. We evaluated 19 traditional $(\mathrm{K}, \mathrm{Kn}$, hepatosomatic index, gonadosomatic index, energy density and percent dry 20 weight of muscle $[\% \mathrm{DWM}]$ and liver $[\% \mathrm{DWL}])$ and newer (bioelectrical impedance analysis $21[\mathrm{BIA}]$ and scaled mass index $[\mathrm{SMI}])$ condition indices to track seasonal cycles in three

22 flatfishes- winter (3 stocks), yellowtail (3 stocks), and summer flounder (1 stock) -with 23 contrasting life histories: in habitat, feeding, and reproduction. The \%DWM and \%DWL were 
24 good proxies for energy density $\left(r^{2}>0.96\right)$ and more strongly related to $\mathrm{K}$, Kn and SMI than to

BIA metrics. Principal component analysis indicated many metrics performed similarly across species; some confounded by size, sex, and maturity along PC1, others effectively characterizing condition along PC2. Stock differences were along PC1 in winter flounder, reflecting different sizes across stocks, whereas in yellowtail flounder differences occurred along PC2 related to condition. These comparisons, within and across species, highlight the broad applicability of some metrics and limitations in others.

\section{Introduction}

The physiological health and energetic status of fishes is increasingly evaluated for a broad range of purposes; as a proxy for reproductive output (Marshall et al. 1999; 2003, 2006), to assess responses to biological interactions (Marshall et al. 2004; Cade et al. 2008), ecosystem change (Choi et al. 2004), as prey to higher trophic levels (Renkawitz et al. 2015), to categorize life history types within a population (Larsen et al. 2017), and to inform population status for management (Blackwell et al. 2000; Brosset et al 2017; Morgan et al. 2018) and conservation (Stevenson and Woods 2006). Depending on the intended purpose (e.g. single species energy content and reproductive potential, or multi-species ecosystem indicators) the desired characteristic of the metric chosen will vary. The concept of overall 'health' of an organism is somewhat ambiguous, and considered to be an integration of many factors acting at the suborganism level that are more clearly defined and quantifiable (e.g. fat content, RNA/DNA, hemoglobin concentration, etc.). The goal of defining the 'best' states of condition in individuals and populations, and deviations from this optima, has been a pursuit of fisheries biologists for many years, and approaches can generally be classified as either morpho-physiological (e.g. 
47 weight at a given length, hereafter referred to as morphological) or physiological-biochemical 48 (Shulman and Love 1999). To be useful, methods should 1- characterize functional features of organisms or populations, 2- encompass the range of variability in the process examined, 3- be 50 representative of the population, and 4- be easily measured under field conditions (Shulman and 51 Love 1999). While physiological-biochemical methods have generally been more informative, 52 they require more effort and are impractical for field sampling and large sample sizes. Numerous methods have been proposed to relate the physiological health (state of wellbeing, condition) of

54 fishes based on physiological-morphological characteristics, with the premise that heavier or 55 fatter is better (Le Cren 1951; Ricker 1975; Hayes and Shonkwiler 2001). The morphological approach offers ease of collection, but still needs to be validated to some functional feature (e.g.

57 energy content), and often fails to accurately reflect nutritional condition of individual fishes.

The nondestructive nature of morphological indices is appealing, especially if they can be related to variables such as fat or energy content that are much more difficult to measure. Simple metrics such as Fulton's K relate the weight of an individual to that predicted from the cube of their

62 length; $K=\mathrm{W} / \mathrm{L}^{3}$. Though Fulton's $\mathrm{K}$ has been in use for many years (Nash et al. 2006), problems related to the assumption of weight scaling as a cube of length have been demonstrated 64 (Cone 1989). Since the exponent of the weight-length relation deviates from 3 in most species, the calculated Fulton's K is dependent on size, invalidating comparison of values from samples

67 exponent, but fits a length-weight relationship to the available data (sample or population). Individual $\mathrm{Kn}$ is then calculated as the observed weight/predicted weight based on length (Le 69 Cren 1951); thus, a value of 1 indicates 'average' condition. One disadvantage of Kn is that 
70 given its 'relative' nature, when additional data is added a new predictive regression is required

71 which can change prior individual Kn values (e.g. with additional sampling or data, what was

72 considered 'average' condition may now be shown to be above or below average). This 'internal'

73 (study-specific) aspect of calculating Kn also makes it difficult to compare values across studies.

74 The relative weight index (Wr; Blackwell et al. 2000) addresses this reliance on an internally

75 estimated length-weight relation by using a standard equation for each species (i.e. a 'global

76 mean') and allows cross study comparison. Wr has been applied more commonly for freshwater

77 species, where it may be impractical to develop length-weight relations for every pond or lake.

78 More recently, Peig and Green (2009) proposed use of a scaled mass index (SMI), which is

79 based on the central principle of scaling. Compared to other (more traditional) morphometric

80 condition indices, the SMI was shown to be a better predictor of fat and energy reserves in a

81 variety of organisms (small mammals, birds and snakes), and has since been applied to a broader

82 range of animals including amphibians (MacCracken and Stebbings 2012) and fishes (Camizuli

83 et al. 2014; Maceda-Veiga et al. 2014; Morita et al. 2015; Masse et al. 2016).

84

85 In addition to advances in analytic methods for morphological condition indices, new

86 technologies have emerged and been applied to quantify physiological condition, including total

87 body electrical conductivity (TOBEC; Scott et al. 2001), bioelectrical impedance analysis (BIA;

88 Cox and Hartman 2005), and the fatmeter (Crossin and Hinch 2005; Davidson and Marshall

89 2010; Schloesser and Fabrizio 2017). Both TOBEC and BIA operate on the principle that the

90 conductivity of an organism is determined mainly by its lean tissues (Scott et al. 2001). BIA has

91 been applied successfully to estimate whole body fat and energy in fish in several studies (Cox 
92 and Hartman 2005; Cox and Heintz 2009; Hafs and Hartman 2011), but less successful in other

93 studies (Pothoven et al. 2008; Garner et al. 2012; Klefoth et al. 2013; Dibble et al. 2017).

95 Regardless of condition index chosen, there is a need to relate any index at different stages in a 96 fish's life to standard physiological variables (e.g. fat or energy density, Davidson and Marshall

97 2010; Schloesser and Fabrizio 2017). For example, because condition indices, whether morphometric or derived from physical [bioelectrical] properties, may reflect different aspects of an individual's physiologyand may be affected differently by both the reproductive state (on an annual cycle; Robards et al. 1999) and reproductive mode of a given species. This study focuses on three species with different life histories, particularly in terms of reproduction, which is 102 energetically demanding and likely to affect fish condition.

Teleosts display a wide diversity in reproductive modes (Smith and Wootton 2016), and energy 105 allocation strategies for reproduction that can be generalized along a continuum from capital to income breeding types that may be a response to seasonal cycles of food availability (McBride et al. 2015). The high fecundity of many fishes (as compared to other vertebrates) requires that fishes devote a large percentage of surplus energy to reproduction. Even within species that spawn multiple seasons in their lifetime (i.e. iteroparous) ovary mass may exceed $40 \%$ of total body mass in the period leading up to spawning. Such substantial buildup and release of gametes

111 is energetically demanding and often requires mobilization (depletion) of stored energy from 112 other parts of the body (e.g. soma, liver). Therefore, in addition to the gonad, the soma, liver, and 113 viscera or mesentery may also fluctuate in response to reproductive condition. Since some of 114 these body components function as energy storage; the seasonal cycles of build-up and depletion 
115 is often temporally offset from that of reproductive output. These internal dynamics within

116 individual fish can confound efforts to assess condition from measures of whole body weight.

117 Therefore, even if the weight of the gonad is accounted for in measures of condition based on

118 weight, the seasonal energetic cycle related to spawning (and/or feeding) may not be fully

119 accounted for in analyses of condition from length-weight data.

121 Here, we measured biochemical measures of condition, as well as morphological and electrical

122 indices, for 3 species. The three species - winter flounder (Pseudopleuronectes americanus),

123 yellowtail flounder (Limanda ferruginea), and summer flounder (Paralichthys dentatus) - were

124 chosen because of their contrasting habitat use, feeding modes, and reproductive patterns (Table

125 1). In terms of habitats, winter flounder is structured as three populations that reside in estuaries,

126 shelf areas, and offshore banks from New Jersey northward; yellowtail flounder is structured in

127 three populations that reside in the New England offshore shelf areas and offshore banks, and

128 summer flounder is a single population distributed in coastal waters and along the shelf in the

129 warm temperate zone, from the Carolinas to Georges Bank. Stock-specific growth, maturity, and

130 fecundity have been reported in both winter (McBride et al. 2013; McElroy et al. 2013) and

131 yellowtail flounder (Klein-MacPhee 2002a; McElroy et al. 2016). Winter flounder is an example

132 of an extreme capital breeder that ovulates an entire annual fecundity at once (i.e. total spawner

133 - Press et al. 2014; McBride et al. 2015; McElroy et al. 2013). Winter flounder spawn benthic

134 eggs and are also unusual in that they spawn in estuaries, but also in nearshore waters (DeCelles

135 and Cadrin 2011; Fairchild et al. 2013), and on Georges Bank (Klein-MacPhee 2002a).

136 Yellowtail flounder is another boreal/temperate species, similar to winter flounder. Although

137 yellowtail flounder fecundity is determinate and oocyte development is group synchronous, they 
138 ovulate and release pelagic eggs in batches and remain in offshore shelf waters. Both winter and

139 yellowtail flounder are benthivores (Link et al. 2002; Smith and Link 2010), feeding primarily on

140 invertebrates (polychaetes, Gammarids, and Anthozoans). Summer flounder also inhabits

141 coastal/shelf habitats, but has a more southerly distribution (temperate-subtropical) and with

142 extensive seasonal movements from coastal waters to the outer continental shelf (Klein-MacPhee

$1432002 b$ ). In contrast to winter and yellowtail flounder, summer flounder have asynchronous

144 oocyte development, continuing to recruit and produce batches of eggs throughout a protracted

145 spawning season; therefore, annual fecundity is indeterminate (Merson et al. 2000). This

146 reproductive pattern is characteristic of income breeders (McBride et al. 2015). Summer flounder

147 attain larger sizes, exhibit more pronounced sex-dimorphic growth, and feed on higher trophic-

148 level prey including fish and squid (Link et al. 2002; Smith and Link 2010; Wuenschel et al. $1492013 a)$.

151 Consequently, winter and summer flounder are at opposite ends of the reproductive spectrum in 152 regard to energy allocation (capital, total spawner vs. income, batch spawner) with yellowtail 153 flounder intermediate between these two ends of this spectrum. Therefore, variation across 154 seasons and among species provides contrast in multiple measures of physiological condition.

155 The objectives of this study were to measure a suite of morphological and physiological-

156 biochemical properties of these three species with different energy allocation strategies to

157 determine inter-relations between the various measures of condition, and therefore the suitability

158 of easily measured 'proxies' to accurately estimate physiological condition. The diversity of life

159 history traits exhibited by these three species encompasses that for a wide range teleosts, so the 160 conclusions drawn from them should be broadly applicable. 
162 Methods

163 Sample sources

164 The collections used here are part of ongoing efforts to investigate and monitor the reproductive 165 biology of three flatfish species - winter flounder, yellowtail flounder, and summer flounder 166 and some aspects of this research have been reported previously (McElroy et al. 2013, 2016; 167 Press et al. 2014). The present analysis includes samples collected using bottom trawls from 168 several sources; the Northeast Fishery Science Center (NEFSC) Northeast Cooperative Research 169 Branch's (CRB) Study Fleet and other CRB field research, the Massachusetts Department of 170 Fish and Game Division of Marine Fisheries (MADMF) bottom trawl survey, the NEFSC

171 Ecosystems Surveys Branch bottom trawl survey, and the University of Rhode Island Graduate 172 School of Oceanography (URI) bottom trawl survey (summarized in Table 2). These sources 173 allowed coverage of portions of the Gulf of Maine, Georges Bank and Southern New England 174 stocks of winter and yellowtail flounder, and the single stock of summer flounder. Immediately 175 after capture, fish were iced down and transported to the laboratory for processing. Intensive 176 monthly sampling of all three species (from seven fishery stocks) was conducted from December 1772009 until spring 2011; after which collections were focused on the reproductive season of each 178 stock in order to conserve resources. Summer flounder collections ceased after winter 2013, but 179 sampling for the other species continued (2014-2016), targeted toward the period just prior and 180 through peak spawning for each stock. 
183 First, BIA was performed on fish in the lab using the Quantum X Body Composition analyzer 184 (RJL Systems Inc.). Electrical resistance and reactance between pairs of electrodes placed in the 185 dorsal musculature of the eyed side were measured while the fish was on a nonconductive 186 measuring board with moveable electrode holders (Fitzhugh et al. 2010). Each electrode pair 187 included a signal emitting and a signal detecting electrode spaced $10 \mathrm{~mm}$ apart. Leads from the 188 device were attached directly to steel dissecting pins set to penetrate a depth of $5 \mathrm{~mm}$. At the 189 start of each sampling session, the resistance and reactance of a standard resistor (500 ohm) 190 connecting directly to the electrodes was measured to ensure all electrical connections were 191 correct and readings were within tolerance (resistance, $500.0+/-5.0$ ohms; reactance $0.0+/-3.0$ 192 ohms). The following anatomical landmarks were used for electrode placement; anterior 193 electrode placed dorsal to the pectoral fin, midway between lateral line and dorsal margin; 194 posterior electrode set aligned with dorsal fin insertion at the caudal peduncle, midway between 195 the lateral line and dorsal margin. From these measured electrical properties, additional 196 bioelectrical properties were calculated (Table 3) following Cox and Hartman (2005), Hafs and 197 Harman (2011), and Stolarski et al. (2014).

199 The following measures were obtained; total length $( \pm 1 \mathrm{~mm})$, total weight $( \pm 0.1 \mathrm{~g})$, sex, maturity, 200 liver weight $( \pm 0.001 \mathrm{~g})$, and gonad weight $( \pm 0.001 \mathrm{~g})$. Maturity was assessed macroscopically 201 following the criteria outlined in Burnett et al. (1989), O'Brien et al. (1993), McBride et al. 202 (2013), and initially assigned to six classes: immature, developing, ripe, running ripe, spent, and 203 resting. For the present analysis, ripe, and running ripe were combined as ripe. Gonadsomatic 204 (GSI) and hepatosomatic (HSI) indices were calculated as 100*([gonad or liver] weight / (body 205 weight - [gonad or liver] weight)), respectively (Wootton 1990). For a subset of individuals of 
206

207

208

209

210

211

212

213

214

215

216

217

218

219

220

221

222

223

224

225

226

227

228

each species additional samples of liver (mean $=7.194, \mathrm{SD}=3.741 \mathrm{~g}$ wet weight $)$ and epaxial muscle (mean $=7.617, \mathrm{SD}=3.865 \mathrm{~g}$ wet weight) tissue were removed to determine the water content (and percentage dry weight).

Liver and epaxial muscle tissue samples were dried at $60^{\circ} \mathrm{C}$ to a constant weight, and the percent dry weight $(\% \mathrm{DW}$; unitless $)$ of muscle and liver tissue was calculated as $\% \mathrm{DW}=100 \times($ dry weight/wet weight $)$. A subset of these samples $(n=266)$ across a range of seasons, sex, maturity classes, and percentages of dry weight for each tissue type and species was selected for proximate composition analysis. Proximate composition of subsamples of dried tissue were analyzed gravimetrically (following Morley et al. 2012), using Soxhlet extraction apparatus with petroleum ether as the solvent to determine lipid content, and then re-drying to a constant weight to determine lipid-free weight. The lean (lipid-free) sample was then combusted in a muffle furnace at $500{ }^{\circ} \mathrm{C}$ for $5 \mathrm{~h}$, cooled to ambient temperature, and re-dried to constant weight to determine ash content. Preliminary analysis indicated $5 \mathrm{~h}$ combustion time was sufficient for the size and composition of these samples (K. Oliveira unpub. data). The lean tissue weight was assumed to be protein; phospholipids and carbohydrates are minor fractions in fish tissue (Love, 1980). Liver energy density ( $\mathrm{LED} \mathrm{kJ} \mathrm{g}^{-1}$ ) and muscle energy density (MED) were calculated per gram wet weight using the energy equivalent values for lipid $(39.54 \mathrm{~kJ} g-1)$ and protein $(23.64$ kJ g-1) (Henken et al. 1986; Morley et al. 2012). Total liver energy (TLE) was then calculated by multiplying the energy density (measured directly or estimated from ED vs. \%DW relationships) by the total liver weight.

Morphometric condition indices 
229 Fulton's $\mathrm{K}$ of individual fish was calculated as $\mathrm{K}=\mathrm{W}_{\mathrm{i}} / \mathrm{L}_{\mathrm{i}}{ }^{3}$, where $\mathrm{W}_{\mathrm{i}}$ and $\mathrm{L}_{\mathrm{i}}$ are the observed 230 individual fish weight and length. Relative condition $(\mathrm{Kn})$ was calculated as $\mathrm{Kn}=$ observed 231 mass/predicted mass $\mathrm{W}_{\mathrm{i}} / \mathrm{aL}_{\mathrm{i}} \mathrm{b}$, where $\mathrm{W}_{\mathrm{i}}$ and $\mathrm{L}_{\mathrm{i}}$ are as above, and a and $\mathrm{b}$ are species-specific 232 regression constants obtained from the overall length weight relationships using pooled data 233 (Table 4). Because sample coverage varied over the course of the study (with later years focused 234 only on the few months leading up to spawning), we developed length-weight equations from the 235 first $\sim 2$ years of collections when (near) monthly samples were obtained. This approach captured 236 the seasonal cycle in weight at length (albeit for only 1-2 spawning seasons) while reducing 237 potential bias due to the predominance of fish in pre-spawning condition in the more recent 238 years.

239 We calculated the scaled mass index (SMI); following Peig and Green (2009) who applied the 240 Thorpe-Lleonart model of scaling (Lleonart et al. 2000) to length-mass:

$$
S M I=M_{i}\left[\frac{L_{0}}{L_{i}}\right]^{b_{S M A}}
$$

243 Where $M_{i}$ is body mass and $L_{i}$ is length of individual $i$, b $\mathrm{S}_{\mathrm{SMA}}$ is the scaling exponent obtained 244 from the species -specific standardized major axis regression of $\ln M$ vs. $\ln L ; L_{0}$ is an arbitrary 245 reference length chosen for standardization; and SMI is the predicted body mass of individual $i$ 246 standardized to $L_{0}$ (Table 4). For the reasoning above for Kn, we used data from the first $\sim 2$ years 247 of sampling to estimate length-weight parameters. As in other studies, we set $L_{0}$ to the arithmetic 248 mean length sampled for each species. 
251 The significance of seasonal variation in physiological measures and morphological condition

252 indices was assessed using the nonparametric Kruskal-Wallis test since the monthly data had

253 unequal variances (Levene's test, $\mathrm{P}<0.05$ ) and/or non-normal distributions (Shapiro-Wilk,

$254 \mathrm{P}<0.05)$ in all cases. Pearson correlation coefficients between the various morphological,

255 physiological, and biochemical measures (summarized in Table 3) were calculated and

256 visualized for each species using the corrplot package in R (Wei and Simko 2016). Linear

257 regressions of the relationships between tissue (muscle and liver) energy density and tissue

258 percent dry weight were developed for each species.

259

260

Multiple morphometric and physiological measures were collected on each specimen, increasing

261 the likelihood of i) redundant (covarying, correlated) variables and ii) high type I error if all

262 combinations were analyzed. Therefore, to evaluate relationships between the multiple

263 morphological and physiological measures recorded for each specimen (i.e. multivariate data) we

264 applied ordination methods to reduce the numbers of axes to capture the main trends in the data.

265 We used principal component analysis (PCA) to explore patterns between morphological,

266 biological, and physiological variables measured for each species. This method is descriptive in

267 nature, and considered an appropriate method to explore structure in the observed variation in the

268 data and allowed us to determine what aspects of 'condition' were captured by each of the

269 indices, thus serving as a validation tool without any a priori assumptions regarding response vs.

270 explanatory variables. The PCA was run using the correlation matrix of the scaled data (unit

271 variance) for all of the continuous variables, and sex, reproductive phase, and stock were

272 included as supplemental (categorical) variables. Individuals missing data for any of the

273 variables were removed prior to analysis. For each species, PCA was performed using the 
274 FactoMineR package (Le et al. 2008) in R statistical software, with results visualized using 275 Factoextra (Kassambra and Mundt 2016). The categorical variables are not used in forming the 276 principal components, therefore the unbalanced nature of our sampling with respect to sex, 277 reproductive phase, or stock did not introduce bias. The categorical variables were 'mapped' 278 onto the PCA space and categories that were characteristic of each principal component were 279 identified (dimdesc function in FactoMineR). The number of principal components retained was 280 based on visual evaluation of the Scree plots of variation explained, and interpretability of the 281 loadings.

283 Results

284 Fish were analyzed from a broad geographic region, encompassing portions of 3 fishery stock 285 areas for winter flounder and yellowtail flounder, however sample sizes were lower from 286 Georges Bank for both (Fig 1.). Summer flounder samples were almost entirely from the 287 Southern New England portion of the stock, but were from both inshore in summer and deeper 288 offshore areas during the colder months.

\section{Condition Metrics}

291 The physiological measures varied across species and seasons, reflecting differential 292 reproductive modes and energy allocation strategies (Fig. 2). In all cases, observed variation in 293 physiological measures across months was significant (Kruskal-Wallis, $\mathrm{P}<0.001$; Table $\mathrm{S} 1$ ).

294 Winter flounder showed extreme variation in GSI through the year, approaching $40 \%$ just prior 295 and during spawning in winter. Yellowtail flounder, a spring spawner, showed a notably large 296 seasonal variation in GSI, but to a lesser degree than winter flounder. Summer flounder, 
297 primarily a fall spawner in this region, demonstrated the least magnitude variation in GSI, with 298 values ranging from $<2 \%$ in the non-spawning period and at maximum $<10 \%$ during spawning. 299 The relative size (median 1-2\% of fish mass) and seasonal variation in size of the liver (HSI) was 300 similar across species, however the composition of the liver (\%DWL) followed distinct seasonal 301 patterns in all species and summer flounder had 5 to $10 \%$ higher peak \%DWL. Winter flounder 302 exhibited less variation in \%DWL than either other species with a range of only $10-12 \%$.

303 Seasonal cycles in muscle composition (\%DWM) were also evident for all three species, with 304 winter and yellowtail flounder having stronger seasonal patterns while summer flounder had 305 higher \%DWM and lower individual variation. Peaks in \%DWM and \%DWL occurred in the 306 non-spawning period for winter and yellowtail flounder. Summer flounder exhibited two peaks 307 for $\% \mathrm{DWM}$ and particularly $\% \mathrm{DWL}$, one occurring in winter and one in summer.

309 The three morphometric condition indices generally captured seasonal changes in fish condition 310 related to spawning seasonality, showing lowest values immediately following spawning and 311 recovering thereafter (Fig. 3). As for physiological measures, in all cases the observed variation 312 in morphometric condition indices across months, although subtle as compared to individual 313 variation, was significant (Kruskal-Wallis, $\mathrm{P}<0.001$; Table $\mathrm{S} 1$ ). The seasonal signal was 314 strongest in winter flounder and weakest in summer flounder. For each species, the patterns 315 observed for K and Kn were similar, while values of SMI indicated more extreme low values for 316 winter and yellowtail flounder. During the spawning seasons for both winter and yellowtail 317 flounder, there were more individuals identified as outliers with low SMI. The patterns in phase 318 angle (PA) were more ambiguous and did not closely follow patterns in $\mathrm{K}$, Kn, and SMI for 
319 winter and yellowtail flounder except for the low values in July for yellowtail flounder. For

320 summer flounder, the PA followed the patterns in morphometric indices.

322 Overall, the observed seasonal patterns in both physiological and morphometric condition

323 indices for winter and yellowtail flounder, generally showed a single peak and valley, whilst in

324 summer flounder there was indication of 2 peaks occurring through the year for many measures.

325 Winter flounder exhibited larger variation than the other species in measures influenced by

326 muscle mass; whereas yellowtail and summer flounder demonstrated larger variation in liver

327 metrics than winter flounder. Within monthly summary boxplots, variation in both physiological

328 and condition indices was large, reflecting the diversity of sexes and reproductive phases

329 sampled. This variation was greater in winter and yellowtail flounder, where the monthly

330 aggregates include fish from multiple stocks with differing peak spawning periods (see Fig. S1).

\section{Correlations}

333 Correlations between physiological and morphometric condition indices within each species 334 revealed several commonalities (Figs. 4, 5, 6). The three morphometric condition indices (K, Kn, 335 SMI) had strong positive correlations with each other, except for SMI of Summer flounder. In all 336 species, both $\mathrm{K}$ and $\mathrm{Kn}$ had weak positive correlations with physiological measures, including $337 \%$ DWL, \%DWM, TLE, GWEIGHT, LWEIGHT, GSI, HSI. For SMI, correlations with these 338 same physiological measures ranged from weakly positive in yellowtail, weakly positive and 339 weakly negative in winter flounder, to no relation or strongly negative in summer flounder. The 340 electrical properties calculated from BIA measures were strongly correlated to each other, but 341 also were strongly correlated to measures of size (TLENGTH, TWEIGHT, GFWEIGHT) and 
342 properties that co-varied with size (GWEIGHT, LWEIGHT). The \%DWL and \%DWM were

343 generally correlated with each other, but none of the morphometric, biological, or BIA measures

344 were strong predictors of $\% \mathrm{DW}$ in these tissues. The TLE was strongly correlated to \%DWL,

345 HSI and LWEIGHT.

346

347 For each species, strong relations were observed between the percentage dry weight of liver and 348 muscle, and the energy content of those tissues (Fig. 7, Table 5). Analysis of variance indicated 349 significant main effect of species on the relationships between energy density and percent dry 350 weight of liver $(P<0.001)$, but the interaction between species and \%DWL was not significant $351(P=0.083)$. Similarly, there was a significant species effect (ANOVA, $P<0.001)$ on the 352 relationship between energy density of muscle and \%DWM, but the interaction term was not 353 significant $(P=0.465)$. Species specific regressions are presented in Table 5. Despite differences 354 in regression intercepts, the data largely overlapped across species, however the range of 355 observed values in \%DWM differed; summer flounder \%DWM was never observed below $356 \quad 18.8 \%$.

\section{PCA summaries}

359 The PCA analyses indicated similar influence (i.e. redundancy) of several variables across 360 species (Table 6). For each species the first principal component was strongly correlated to direct 361 measures of fish size (e.g. TLENGTH, TWEIGHT, GFWEIGHT, LWEIGHT, GWEIGHT) as 362 well as size-dependent (i.e. not standardized to detector length) BIA measures (e.g. RS, CPF, ZS, 363 RP, ZP, XC, and XCP; Figs. 8, 9, and 10). Across species, the second principal component was 364 generally related to various measures of condition ( $\mathrm{K}, \mathrm{Kn}, \mathrm{SMI}, \mathrm{BMI}, \mathrm{PA})$. The third and fourth 
365 principal components were significantly correlated with several variables, however, they 366 generally explained low amounts of variation (5.7-10.8).

368 For winter flounder, the first principal component axis explained $48.7 \%$ of the observed variance, and was highly correlated to several measures associated with size (Table 6). The 370 second PC explained an additional 17.6\% and was influenced by the morphometric condition 371 indices (K, Kn, SMI). The third PC explained $10.8 \%$ of the variation, and was most related to 372 three BIA measures (PADL, REACT, and PA). Finally, the fourth PC explained 7.2\% of the 373 variance, and was related to \%DWM, \%DWL, and GSI. Visualizations of data grouped by 374 qualitative variables (reproductive phase, sex, stock) revealed the following; immature 375 individuals were grouped on the left of PC 1 (associated with smaller size), developing 376 individuals were generally higher along PC2 (higher condition) while spent fish were lower on 377 this axis (i.e. lower condition; Table 6, Fig. 8). Sex did not show as strong effects, but did show 378 some influence related to fish size (PC1), i.e. higher values associated with the larger size 379 reached by females. The stock effect was largely along PC1, driven by the larger size of the 380 individuals in the GB stock (Fig. 11).

382 For yellowtail flounder, the first PC explained $42.1 \%$ of the overall variation, and was also 383 highly correlated to measures associated with size (Table 6). The second PC explained an 384 additional $23.8 \%$ of the variation, and was influenced primarily by morphometric and BIA 385 condition metrics (K, Kn, SMI, BMI, PA, and PADL). The third PC explained an additional $38610.8 \%$ of the variation, but except for PADL the correlations with individual variables were 387 weaker. The fourth PC explained $7.9 \%$ of the variation and was influenced by \%DWL and GSI. 
388 Visualizations of the data by qualitative grouping variables revealed the following; immatures

389 and males grouped to the left on PC1 (smaller sized), and spent fish were generally lower on PC2

390 (i.e. lower condition; Table 6, Fig. 9). Stock differences in yellowtail flounder were stronger

391 along PC2 (i.e. condition) than PC1; the GB stock had more variable and lower condition,

392 particularly for larger fish (higher PC1), and more SNE fish had higher condition (Fig. 11).

394 For summer flounder, the first PC explained 57.2\% of the observed variation in the data, and was 395 again dominated by measures associated with size (Table 6), but also included K. The second PC 396 explained an additional $13.4 \%$ of the variance and was related to condition measures $\mathrm{Kn}$, SMI

397 and K. The third PC explained 7.9\% variance, and was most strongly associated with PA and 398 REACT. The fourth PC explained only $5.7 \%$ of the variation and was positively correlated with 399 GSI in contrast to the other 2 species. Visualizations of the data by qualitative grouping variables 400 revealed the following; immature and male individuals were on the left of axis 1, (smaller size), 401 and spent fish were slightly lower on axis 2 (low condition; Table 6, Fig. 10). Regional (stock) 402 effects were not evaluated for summer flounder.

404 Discussion

405 Herein we document large variation in the physiological state of individuals both within and 406 across species. Variation occurred seasonally and across sexes, and was due in part to species407 specific reproductive and energy allocation patterns. Additional variation was evident across 408 stocks, reflecting large scale environmental drivers on growth, feeding, and energetics. 409 Morphological indices (based on external and internal characteristics) captured large scale 410 seasonal differences in condition at the organism level, but were less predictive of bio-chemical 
411 condition at the sub-organism level (e.g. energy density of muscle and liver). Some intermediate

412 measures, with respect to ease of collection, such as the percentage dry weight of tissue, were

413 good predictors of tissue energy density. Bioelectrical measures generally performed poorly at

414 both the organism and sub-organism scales. Principal Component Analyses provided a

415 comprehensive summary of the inter-relations between various condition measures, and how

416 these relationships varied across these three species with very different life histories providing

417 insights that are applicable to many other species. A more detailed description of the variation in

418 fish condition that occurs at various levels (sub-organism, organism, population), the ability of

419 old and new metrics to capture this variation, and therefore the conclusions and advice that can

420 be drawn from them follows.

421

422 Seasonal patterns of condition in relation to reproductive strategy and energy allocation

423 Seasonal cycles in physiological and morphometric variables were evident, even when

424 considering that the summary boxplots (Figures 2, 3) combined sexes and stocks. Variation in

425 spawning season among stocks is well documented for both winter flounder (McBride et al.

426 2013; McElroy et al. 2013; Press et al. 2014) and yellowtail flounder (McElroy et al., 2016).

427 Aggregating data by month across multiple years, stocks, sexes, and maturity stages likely

428 contributed to the large amount of individual variability in GSI, HSI and percent dry weight of

429 liver and muscle and dampened the seasonal patterns. Variations among species were also

430 evident, because the reproductive strategies of these three flatfishes follow different processes of

431 energy acquisition, storage, and depletion.

Of the three species studied here, winter flounder underwent the widest seasonal ranges

433 in condition, with significant storage and depletion of energy from muscle tissue. This has been 
434 previously documented, with greater variation reported for more northern populations (Plante et

435 al. 2005; Wuenschel et al. 2009). There was limited seasonal variation in liver tissue composition

436 of winter flounder, in contrast to the other two species. Starvation of captive winter flounder was

437 found to result in depletion of a hypodermal lipid layer along the midline, and produced water

438 content levels in the muscle tissue higher (88-95\%) than any observed in wild fish in the current

439 study (Maddock and Burton 1994). The importance of the seasonal timing of feeding and fish

440 condition to reproductive participation has been demonstrated in captive experiments on winter

441 flounder, with poor condition inducing skipped spawning (Burton and Idler 1987; Burton 1994).

442 The characteristics of winter flounder spawning, particularly as a determinate, high fecundity,

443 and total spawner during winter, require this species to utilize its energy reserves ('capital')

444 extensively and results in the strong seasonal cycles in condition and \%DWM.

446 Yellowtail flounder also undergo a wide range of condition changes seasonally, and showed

447 more individual and seasonal variation in the percent dry weight of liver (and to a lesser degree

448 HSI). Yellowtail flounder also had more individuals at the low end of the \%DWM distributions

449 (outliers and lower $25 \%$ percentile) over more months. This species was comparable in its

450 patterns to winter flounder, but utilized liver reserves to a greater extent than winter flounder.

451 Dwyer et al. (2003) reported laboratory-reared yellowtail flounder had higher levels of HSI and

452 lipids in the muscle and liver than wild fish, which they attributed to efficient absorption from

453 the diet and rapid deposition in tissues; therefore, the observed seasonal patterns in the current

454 study likely reflect changes in food quality and/or feeding intensity. In addition, the energy usage

455 of both muscle and liver reserves may reflect its 'capital' pattern of reproductive energy usage,

456 but it may be somewhat intermediate compared to the other two species in using both liver and 
457 muscle extensively. The species has been shown to exhibit variable levels of down-regulation of

458 fecundity in the period just prior to spawning (McElroy et al. 2016), which may be dependent on 459 available energy reserves (i.e. liver and muscle).

460

461 Disease may also play a role in the broad range of \%DWL observed among yellowtail flounder.

462 The protozoan parasite Ichthyophonus sp. was recently reported in the Georges Bank stock of 463 yellowtail flounder (Huntsberger et al. 2017) and we occasionally observed macroscopic lesions 464 associated with infection (nodules of firm white cysts on the surface of the liver and other 465 peritoneal organs) in all stocks. It is possible the greater variation in percent dry weight of liver 466 in yellowtail flounder is caused by varying infection intensities, with encysted parasites affecting 467 the percentage dry weight and energy content of the liver tissue sample. Interestingly, the 468 relationship between percentage dry weight of liver and liver energy density for yellowtail 469 flounder had a lower $r^{2}$ value than the other two species, however it was still highly correlated $\left(r^{2}\right.$ $470=0.96$, Table 4). Infection by Ichthyophonus sp. can spread to other tissues, including muscle 471 and heart, and it is considered to be debilitating and/or lethal in yellowtail flounder (Huntsberger 472 et al. 2017). Therefore, it is possible that variation in liver condition of yellowtail is reflective of 473 systemic infection in other parts of the body. Although not measured for these samples, increased 474 infection prevalence and intensity may explain some of the low outliers observed for yellowtail 475 flounder in $\mathrm{K}, \mathrm{Kn}, \% \mathrm{DWL}$, and \%DWM, which were more common in this species than the 476 other two. This underscores the potential importance of infection and its impacts on growth, 477 reproduction, and condition particularly given the low population status and limited recovery of 478 several of the yellowtail flounder stocks (Northeast Fisheries Science Center 2017). 
480 Compared to the other two species, summer flounder exhibited a higher condition with less

481 seasonal variation in percent dry weight of muscle, except for winter flounder in fall. Summer

482 flounder had higher percent dry weight of liver, which varied over two distinct cycles per year,

483 first peaking in February then again in July-August. Two peaks in liver and muscle condition

484 could be related to the following; 1) summer flounder undergo significant seasonal migrations,

485 moving offshore and south in winter, and 2) in addition to the main spawning season occurring

486 in the fall, summer flounder (particularly larger/older individuals) are known to also have a more

487 limited spawning in the spring (evidenced by higher GSI in some individuals during March-

488 April, Figure 2). Ingressing larvae collected north of Cape Hatteras were mostly fall spawned,

489 while those south of Cape Hatteras were mostly spring spawned, however some overlap in each

490 region was evident (Able et al. 2011). Migration and seasonal prey availability likely plays a

491 larger role influencing the bi-modality of liver and muscle energy, by late April and early May

492 summer flounder had moved to inshore waters and condition readily improved in subsequent

493 months. The more limited change in muscle energy in fall and greater use of liver reserves (more

494 reflective of short term changes) is consistent with the characterization of this species having

495 'income' type reproductive energy allocation pattern.

496

497 Interpretation of morphological condition indices - what are they measuring?

498 The overall seasonal patterns provided contrast in multiple metrics at the organism and sub499 organism scales, and by including all of these variables in the same multivariate analysis we 500 were able to summarize relationships between them. PCA variables represented by vectors that 501 point in the same direction have a similar response profile, convey similar meaning (i.e. may be 502 redundant, whereby simpler measures are suitable proxies for more difficult ones). Condition 
503 indices derived from morphological (external- e.g. length, weight; internal- e.g. liver or gonad 504 weight) properties of fishes are widely used owing their ease of application; however the value 505 of such indices to serve as reliable proxies for biochemical condition is often equivocal

506 (Davidson and Marshall 2010; McPherson et al. 2011; Brosset et al. 2015; Sardenne et al. 2016; 507 Morgan et al. 2018). For the three species investigated here, external morphological condition 508 indices provided marginal direct estimates of measured biochemical condition (muscle and liver 509 energy density). For both winter and yellowtail flounder, the PCA loadings for morphological 510 (K, Kn, SMI) and biochemical (\%DWM, \%DWL) variables were both aligned with PC2, 511 supporting use of these metrics to infer biochemical condition. One drawback of using Kn for 512 monitoring studies is the need to recalculate LW regression to obtain the predicted weight, as 513 new observations are added. In the present study we partially avoided this; the 'new' data we 514 have added throughout the study was not seasonally balanced so we opted to avoid biasing of 515 new LW equations and continued to use those determined during the first years of seasonally 516 balanced samples. This modification has potential to shift the center of observation from 1, but 517 we feel it still provides the interpretability we are after (i.e. fish greater than 1 are 'above' 518 average). The biochemical variables were less strongly associated with PC2 for summer 519 flounder, cautioning the use of $\mathrm{K}, \mathrm{Kn}$, or SMI to infer biochemical condition. Contrast in 520 external morphological condition indices (e.g. $\mathrm{Kn}$ ) has been identified as a prerequisite for 521 significant correlations with biochemical indices. Lambert and Dutil (1997) found significant 522 correlations for cod (Gadus morhua, Kn range 0.45 to 1.2), while correlations for tropical tunas 523 were not significant (bigeye, skipjack, and Yellowfin tuna; Kn range 0.8-1.2) (Sardenne et al. 524 2016). Kn of winter and yellowtail flounder ranged widely across seasons (0.6 - 1.4; Fig. 3), and 525 sampling over multiple years captured variation in condition to reasonably test relationships. 
526 Even with this contrast, although the morphometric indices aligned with PC2 (i.e. condition),

527 they performed poorly as single predictors of biochemical condition. Kn of summer flounder was

528 more stable, but still exhibited seasonal variation (Kn $0.7-1.3)$ that was weakly correlated to

529 biochemical condition. The biochemical condition indices evaluated here (muscle and liver

530 energy density) may not capture the 'overall' condition given they are derived from specific

531 body components; however, muscle and liver are major sites of energy storage in fishes.

532

533

534

535

536

537

538

539

540

541

542

543

544

545

546

547

548

\section{Relationship between percentage dry weight of muscle and liver and energy density}

As in other studies, we found strong relationships between the percentage dry weight and energy density of fish tissue, in this case for liver and muscle. Percent dry weight is well documented as a good predictor of energy density of whole fish (Hartman and Brandt 1995; Schreckenbach et
al. 2001; Glover et al. 2010; Johnson et al. 2017) and fish tissue (Morley et al. 2012; Wuenschel

et al. 2013b). While this relationship can vary across taxonomic groups and ontogenetic stages (Hartman and Brandt 1995; Wuenschel et al. 2006; Schloesser and Fabrizio 2015, 2017), the three flatfishes evaluated here were remarkably similar in energy density at a given percentage dry weight. One notable difference was the range in percent dry weight of muscle observed for each species, where summer flounder was found to maintain higher muscle energy (i.e. not deplete it) throughout the year, and especially following spawning. This finding is consistent with the assumption that summer flounder is largely an 'income' breeder, allocating ingested energy directly to reproduction during a protracted spawning period. The lipid composition of adult summer flounder prey (fish and squid) has a role in maintaining higher energy levels throughout the year compared to the other two flatfishes. Although the three species also had similar and strong relations in percentage dry weight of liver and the energy density of the liver, 
549 a slight curvilinear effect was apparent. This implies less lipid (energy) is stored until a threshold

550 level of percentage dry weight is reached, possibly reflecting changes in structural components in

551 the liver. Liver glycogen and lipid levels of cultured yellowtail flounder were higher than wild

552 fish, and females had more lipids in hepatocytes than males (Fahraeus-Van Ree and Spurrell, 553 2003). A much more pronounced bi-phasic relation has been shown in the muscle of bluefish 554 (Morley et al. 2012).

Evaluation of alternatives to traditional morphometric condition indices

557 Given the limited utility of traditional morphological condition indices to capture changes in 558 biochemical condition of fishes, various methods have recently been proposed, including the 559 scaled mass index (Peig and Green 2009) and bioelectrical impedance analysis (BIA; Cox and 560 Hartman 2005; Cox et al. 2011; Hartman et al. 2015). As in other applications (Peig and Green 561 2010; Maceda-Veiga et al. 2014), patterns in SMI were different than other condition metrics 562 based on external morphology (e.g. K, Kn). In winter and yellowtail flounder, SMI was poorly 563 correlated with all measures evaluated. The PCAs for these two species indicated low 564 contribution of SMI to explaining variation in the data. While in summer flounder, SMI was 565 negatively correlated with size (TLENGTH and other measures strongly related to TLENGTH, 566 GWEIGHT, LWEIGHT). The contribution of SMI to the summer flounder PCA was greater and 567 significant, but was not strongly aligned with either PC1 or PC2, complicating interpretation. In all three species $\mathrm{K}$ and $\mathrm{Kn}$ were significantly positively correlated with percentage dry weight 570 of muscle and liver, but the relationships were generally weak ( $r=0.4$ to 0.5 ) while SMI had very 571 weak or insignificant correlations with these two measures. K, which has been shown to have 
572 significant length bias was not strongly correlated with length in winter or yellowtail flounder,

573 but was more strongly correlated for summer flounder (where a larger range in sizes was

574 analyzed). This may be due in part to sources of material analyzed (predominately commercial

575 gears) that collected a more limited size distribution. In addition, given the current low levels of

576 the yellowtail and winter flounder stocks (Northeast Fisheries Science Center 2017), larger sizes

577 and older ages were not encountered and analyzed, which may have reduced our ability to detect

578 differences due to size. For each species, the largest size analyzed herein was much lower than

579 maximum sizes reported (Tables 1, 2; winter flounder 548 vs. 640 mm; yellowtail flounder 503

580 vs. $640 \mathrm{~mm}$; summer flounder 736 vs. $940 \mathrm{~mm}$ ). Due to potential for size bias in K, especially

581 for fishes with dimorphic growth (including the three species studied here), comparisons should

582 be limited to samples of similar size and sex.

583

584 Bioelectrical variables were poorly correlated with morphological condition metrics (K, Kn, 585 SMI) in winter and yellowtail flounder. Phase angle, calculated from BIA measured resistance 586 and reactance, has been positively related to body condition (Cox and Heintz 2009), weakly 587 related to future gonadal investment (Wuenschel et al. 2013b) and may be sensitive to medium588 term metabolic states (e.g., integrated over weeks).

590 The BIA for the three flounders studied here was collected in a standardized manner using an 591 electrode holder assembly to minimize variation due to electrode stability, placement, and 592 measurement of electrode distance. In contrast to other BIA studies, the data reported here were 593 obtained from dead fish that were iced for varying periods, which has been shown to affect BIA 594 readings (Cox and Heintz 2009; Cox et al. 2011). The resistance of Coho salmon remained stable 
595 for more than $24 \mathrm{hr}$ after death, while the reactance began to change within a few hours (Cox et 596 al. 2011), therefore the BIA measures reported here from fish samples ( $\sim 12$ to $24 \mathrm{hr}$ ) after death 597 likely do not accurately reflect values for those same fish when alive, potentially adding 'noise' 598 and obscuring more positive relations. Knowing this potential limitation, we hoped a strong 599 'signal' given the wide range of condition would overcome the variation due to time after death, 600 but this did not occur. Other aspects of sample quality were not affected in a similar manner, 601 including the percentage dry weight analyses of liver and muscle, and gonad histology (see Press 602 et al. 2014); BIA seems especially sensitive to 'freshness' of the sample.

Although BIA is reflective of somatic muscle energy of juvenile salmonids (Hanson et al. 2010), 605 relations between muscle energy (muscle percent dry weight) and BIA measures were weak in 606 the flatfishes examined here. Hartman et al. (2015) recently reviewed application of BIA in fish 607 studies, noting successes and failures, with recommendations for obtaining accurate estimates of 608 body composition in fish. One well documented potential limitation of BIA measures is the need 609 to consider temperature effects on measured resistance and reactance (Hartman et al 2011; Hafs 610 and Hartman 2015). In the present study all measurements were obtained in the lab, at a 611 consistent temperature, so variation in temperature at time of measurement is not considered to 612 be a significant source of error in our results. BIA measures have been shown to be sensitive to 613 the freezing process (Cox 2015), and used as an indicator of previously frozen samples (Vidacek 614 et al. 2008, 2012), which may have occurred for some of our samples while on deck during 615 winter months and then transported on ice. In addition, our laboratory protocol included testing 616 resistance and reactance through the needle electrodes for a known resistor wired with electrical 617 clips directly connected to the needle electrodes. This ensured the unit and electrodes provided a 
618 solid connection prior to each sampling session, and it is considered to be an improvement over

619 other protocols that tested standard resistors but not through the entire needle electrode assembly.

620 Studies have also noted experience as a potential source of error (Cox et al. 2011), which was

621 minimized in our study where measures were made by few $(<5)$ individuals, with substantial

622 training, oversight, and overlap.

623

624 Bioelectrical variables were highly correlated with each other, and also with many size related

625 measures, which can be problematic. Given the electrical properties were all calculated using the 626 measured resistance and/or reactance, it is not surprising that many of these variables were

627 strongly correlated with each other (see Dibble et al. 2017). Despite the inherent co-

628 dependencies between these calculated BIA variables, studies have often included many likely

629 redundant variables in regression models developed to predict body composition from BIA

630 measures (e.g. Hafs and Hartman 2011; Hartman et al. 2011; Hafs and Hartman 2014; Stolarski

631 et al 2014). In practice, when such co-dependencies exist in the underlying data, the parameter

632 estimates and significance of given variables are unstable and change with the addition of 'new'

633 data, limiting their predictive value. This may explain why different studies (even on

634 similar/related species) have included different sets of BIA variables in predictive models (Cox

635 and Hartman 2005; Rasmussen et al. 2012; Hafs and Hartman 2014). In general, the results of

636 the PCA for each species indicated several BIA variables were strongly related to size (i.e. PC1)

637 while others were more related to condition (i.e. PC2), but in each case BIA variables explained

638 less or similar amounts of variation (shorter vectors in bi-plots and lower variable loadings,

639 Table 5) than either traditional size metrics (along PC1), or condition metrics (along PC2). The

640 energetic variables analyzed here were percentage-based (i.e. percentage dry weight of muscle 
641 and liver tissue) and not whole body estimates (e.g. total body water, lipid, energy) which have

642 generally been more successfully related to BIA (Hartman et al. 2015). As in other studies

643 demonstrating low success of BIA to predict percentage based metrics (Pothoven et al. 2008;

644 Calderone et al. 2011) our results suggest BIA is of limited value to estimate percent dry weight 645 and energy content of muscle and liver in these three flatfish.

646

647 Available metrics to assess fish condition actually quantify different aspects of condition,

648 therefore the optimal metric for any study will depend on the specific goals or objectives (e.g.

649 single species energy content and reproductive potential, or multi-species ecosystem indicators).

650 The life history (particularly reproductive strategy) and energy allocation (e.g. where are lipids

651 stored) mode of a study species can also influence the utility of certain metrics, and in some

652 cases several may need to be evaluated to identify the most appropriate. Fulton's K and relative

653 condition Kn performed similarly, however Kn has advantages of being centered on 1 and is thus

654 more easily interpreted. The scaled mass index was slightly more complicated to calculate (as

655 compared to $\mathrm{K}$ and $\mathrm{Kn}$ ) and provided little additional explanatory power to these simpler metrics

656 in the correlation plots and the PCAs. In addition, while SMI tracked condition of winter and

657 yellowtail flounders, its values for summer flounder confounded fish size and condition.

658 Although some condition metrics offer simplicity, they may not reflect the same aspects of 659 condition across species or life stages. Therefore, interpretation of simple morphometric indices

660 is limited without validation to more specific indices (e.g. fat or energy content). BIA measures

661 were not indicative of condition. Gonadosomatic or hepatosomatic indices are appropriate

662 metrics of seasonal condition around reproductive seasons within a single stock but the scale

663 tends to vary by species, complicating multi-species comparisons. The percentage dry weight is a 
664

665

666

667

668

669

670

671

672 List of figures/ Figure Captions

673 Fig. 1. Distributions of sample locations for winter, yellowtail, and summer flounder on the

674 Northeast US continental shelf. Symbols scaled to sample sizes from each location, and stock

675 regions indicated. The dark and light gray lines indicate the 50 and $200 \mathrm{~m}$ isobaths, respectively,

676 and the dashed line indicates the EEZ boundary. Stock regions (Georges Bank, GB; Gulf of

677 Maine GOM; Southern New England, SNE) apply to winter and yellowtail flounder.

678 Fig. 2. Monthly gonadosomatic index (GSI), hepatosomatic index (HSI), percent dry weight of

679 liver (\%DWL) and muscle (\%DWM) of winter, yellowtail and summer flounder. Box plots

680 indicate median (line within each box), $25^{\text {th }}$ and 75 percentiles (box limits), extremes of the data

681 determined as $1.5 *$ interquartile range (whiskers), and any outliers (circles). See Table 3 for

682 variable descriptions.

683 Fig. 3. Monthly morphometric indices (K, Kn, SMI) and phase angle (PA) of winter, yellowtail, 684 and summer flounder. Box plots indicate median (line within each box), $25^{\text {th }}$ and 75 percentiles 685 (box limits), extremes of the data determined as $1.5 *$ interquartile range (whiskers), and any 
686 outliers (circles). See Table 3 for variable descriptions; SMI for each species calculated using $L_{0}$

$687=$ mean size collected for each species.

688 Fig. 4. Correlation matrix of energetic and morphometric variables for winter flounder (see Table 6893 for variable descriptions and abbreviations). The shape and color of the ellipses indicate the 690 strength and sign of correlations between pairs of variables. Non-significant correlations $691(P>0.05)$ are indicated with an X.

692 Fig. 5. Correlation matrix of energetic and morphometric variables for yellowtail flounder (see 693 Table 3 for variable descriptions and abbreviations). The shape and color of the ellipses indicate 694 the strength and sign of correlations between pairs of variables. Non-significant correlations $695(P>0.05)$ are indicated with an $\mathrm{X}$.

696 Fig. 6. Correlation matrix of energetic and morphometric variables for summer flounder (see 697 Table 3 for variable descriptions and abbreviations). The shape and color of the ellipses indicate 698 the strength and sign of correlations between pairs of variables. Non-significant correlations $699(P>0.05)$ are indicated with an $\mathrm{X}$.

700 Fig. 7. Relationship between percentage dry weight of liver and muscle and energy density for 701 winter, yellowtail, and summer flounder. See Table 5 for regression parameters and test 702 statistics.

703 Fig. 8. Summary PCA plots for winter flounder, (a) screeplot, (b) variables bi-plot showing 704 contribution from each variable, (c), individuals plotted by reproductive phase, (d), individuals 705 plotted by sex. See Table 3 for variable descriptions and abbreviations.

706 Fig. 9. Summary PCA plots for yellowtail flounder, (a) screeplot, (b) variables bi-plot showing 707 contribution from each variable, (c), individuals plotted by reproductive phase, (d), individuals 708 plotted by sex. See Table 3 for variable descriptions and abbreviations. 
709 Fig. 10. Summary PCA plots for summer flounder, (a) screeplot, (b) variables bi-plot showing 710 contribution from each variable, (c), individuals plotted by reproductive phase, (d), individuals 711 plotted by sex. See Table 3 for variable descriptions and abbreviations.

712 Fig. 11. PCA bi-plots showing stock effects for winter flounder (a) and yellowtail flounder (b).

713

714 
715 716 717 718 719 720 721

722 723 724 725 726 727 728

\section{Acknowledgments}

This study was funded by the National Oceanic and Atmospheric Administration (NOAA), Northeast Fisheries Science Center (NEFSC) and Cooperative Research Branch (CRB). Most samples were provided by the CRB's Study Fleet. We appreciate the work of all the Study Fleet staff (especially J. Hoey, J. Moser, M. Ball, D. St. Amand) and all the participating fishermen. We thank all the staff members of these various programs: the officers and crew of the NOAA research vessel H. B. Bigelow and the scientific staff of the Ecosystems Surveys Branch of the NEFSC; J. King, M. Camisa, V. Manfredi, and M. Symanski of the MADMF; J. Collie and A. Malek of URI. Finally, we thank E. Tholke, Y. Press, M. Winton, and J. Dayton (NEFSC) for the contributions to data collection, protocol development; A. Aruda for proximate composition analysis of tissue samples; Phil E. Speshel for inspiration; L. Smith, S. Gaichas, C. Legault, and anonymous reviewers for helpful comments on the manuscript. Mention of any products is for descriptive purposes and does not indicate endorsement by NOAA Fisheries.

\section{Literature cited}

Able, K.W., Sullivan, M.C., Hare, J.A., Bath-Martin, G., Taylor, J.C., and Hagan, R. 2011. Larval abundance of summer flounder (Paralichthys dentatus) as a measure of recruitment and stock status. Fish. Bull. 109(1): 68-78.

Blackwell, B.G., Brown, M.L., and Willis, D.W. 2000. Relative weight (Wr) status and current use in fisheries assessment and management. Rev. Fish. Sci. 8: 1-44.

Brosset, P., Fromentin, J.M., Menard, F., Pernet, F., Bourdeix, J.H., Bigot, J.L., Van Beveren, E., Roda, M.A.P., Choy, S., and Saraux, C. 2015. Measurement and analysis of small pelagic 
fish condition: A suitable method for rapid evaluation in the field. J. Exp. Mar. Biol. Ecol. 462: 90-97.

Brosset, P., Fromentin, J.M., Van Beveren, E., Lloret, J., Marques, V., Basilone, G., Bonanno, A., Carpi, P., Donato, F., Kec, V.C., De Felice, A., Ferreri, R., Gasparevic, D., Giraldez, A., Gucu, A., Iglesias, M., Leonori, I., Palomera, I., Somarakis, S., Ticina, V., Torres, P., Ventero, A., Zorica, B., Menard, F., and Saraux, C. 2017. Spatio-temporal patterns and environmental controls of small pelagic fish body condition from contrasted Mediterranean areas. Prog. Oceanogr. 151: 149-162.

Burnett, J., L. O'Brien, R. K. Mayo, J. A. Darde, and M. Bohan. 1989. Finfish Maturity Sampling and Classification Schemes Used During Northeast Fisheries Center Bottom Trawl Surveys, 1963-1989. NOAA Tech. Memo. NMFS-F/NEC-76.

Burton, M.P., and Idler, D.R. 1987. An experimental investigation of the non-reproductive, postmature state in winter flounder. J. Fish Biol. 30(6): 643-650.

Burton, M.P.M. 1994. A critical period for nutritional control of early gametogenesis in female winter flounder, Pleuronectes americanus (Pisces:Teleosti). J. Zool. London 233(3): 405-415.

Cade, B.S., Terrell, J.W., and Porath, M.T. 2008. Estimating fish body condition with quantile regression. N. Am. J. Fish. Manage. 28(2): 349-359.

Caldarone, E.M., MacLean, S.A., and Sharack, B. 2012. Evaluation of bioelectrical impedance analysis and Fulton's condition factor as nonlethal techniques for estimating short-term responses in postsmolt Atlantic salmon (Salmo solar) to food availability. Fish. Bull. 110(2): 257-270.

Camizuli, E., Monna, F., Scheifler, R., Amiotte-Suchet, P., Losno, R., Beis, P., Bohard, B., 
Chateau, C., and Alibert, R. 2014. Impact of trace metals from past mining on the aquatic ecosystem: A multi-proxy approach in the Morvan (France). Environ. Res. 134: 410-419.

762 763

764 765

766

767 768 769 770

771 772

773

774 775 776 777 778 779 780 781 782

Choi, J.S., Frank, K.T., Leggett, W.C., and Drinkwater, K. 2004. Transition to an alternate state in a continental shelf ecosystem. Can. J. Fish. Aquat. Sci. 61(4): 505-510.

Cone, R.S. 1989. The need to reconsider the use of condition indices in fishery science. Trans. Am. Fish. Soc. 118(5): 510-514.

Cox, M.K. 2015. Bioelectrical Impedance Analysis Measures of Body Composition and Condition, and Its Sensitivity to the Freezing Process. J. Aquat. Food Prod. Tech. 24(4): 368-377.

Cox, M.K., and Hartman, K.J. 2005. Nonlethal estimation of proximate composition in fish. Can. J. Fish. Aquat. Sci. 62(2): 269-275.

Cox, M.K., and Heintz, R. 2009. Electrical phase angle as a new method to measure fish condition. Fish. Bull. 107(4): 477-487.

Cox, M.K., Heintz, R., and Hartman, K.J. 2011. Measurements of resistance and reactance in fish with the use of bioelectrical impedance analysis: sources of error. Fish. Bull. 109(1): $34-47$.

Crossin, G.T., and Hinch, S.G. 2005. A nonlethal, rapid method for assessing the somatic energy content of migrating adult Pacific Salmon. Trans. Am. Fish. Soc. 134(1): 184-191.

Davidson, D., and Marshall, C.T. 2010. Are morphometric indices accurate indicators of stored energy in herring Clupea harengus? J. Fish Biol. 76(4): 913-929.

DeCelles, G.R., and Cadrin, S.X. 2011. An interdisciplinary assessment of winter flounder (Pseudopleuronectes americanus) stock structure. J. Northwest Atl. Fish. Sci. 43: 103120. 
783 784 785 786 787 788 789 790 791 792 793 794 795 796 797 798 799 800 801 802 803 804 805

Dibble, K.L., Yard, M.D., Ward, D.L., and Yackulic, C.B. 2017. Does bioelectrical impedance analysis accurately estimate the physiological condition of threatened and endangered desert fish species? Trans. Am. Fish. Soc. 146: 888-902.

Dwyer, K.S., Parrish, C.C., and Brown, J.A. 2003. Lipid composition of yellowtail flounder (Limanda ferruginea) in relation to dietary lipid intake. Mar. Biol. 143(4): 659-667.

Fahraeus-Van Ree, G.E., and Spurrell, D.R. 2003. Structure of and energy reserves in the liver of wild and cultured yellowtail flounder, Limanda ferruginea. Mar. Biol. 143(2): 257-265.

Fairchild, E.A., Siceloff, L., Howell, W.H., Hoffman, B., and Armstrong, M.P. 2013. Coastal spawning by winter flounder and a reassessment of Essential Fish Habitat in the Gulf of Maine. Fish. Res. 141: 118-129.

Fitzhugh, G.R., Wuenschel, M.J., and McBride, R.S. 2010. Evaluation of bioelectrical impedance analysis (BIA) to measure condition and energy allocated to reproduction in marine fishes. J. Phys. Conf. Ser. 224(1): 012137 doi:012110.011088/011742016596/012224/012131/012137.

Garner, S.B., van der Ham, J.L., Boswell, K.M., and Cowan, J.H. 2012. Use of Bioelectric Impedance Analysis to Assess Total-Body Condition and Predict Energy Density in Juvenile Atlantic Croaker. Trans. Am. Fish. Soc. 141(4): 1117-1125.

Glover, D.C., DeVries, D.R., Wright, R.A., and Davis, D.A. 2010. Sample Preparation Techniques for Determination of Fish Energy Density via Bomb Calorimetry: An Evaluation Using Largemouth Bass. Trans. Am. Fish. Soc. 139(3): 671-675.

Hafs, A.W., and Hartman, K.J. 2011. Influence of electrode type and location upon bioelectrical impedance analysis measurements of brook trout. Trans. Am. Fish. Soc. 140(5): 12901297. 
806 807 808 809

810

811

812

813

814

815

816

817

818

819

820

821

822

823

824

825

826

827

828

Hafs, A.W., and Hartman, K.J. 2014. Developing bioelectrical impedance analysis methods for age-0 brook trout. Fisheries Manag. Ecol. 21(5): 366-373.

Hafs, A.W., and Hartman, K.J. 2015. Development of temperature correction equations for bioelectrical impedance analysis models for brook trout Salvelinus fontinalis. J. Fish Biol. 86(1): 304-316.

Hanson, K.C., Ostrand, K.G., Gannam, A.L., and Ostrand, S.L. 2010. Comparison and Validation of Nonlethal Techniques for Estimating Condition in Juvenile Salmonids. Trans. Am. Fish. Soc. 139(6): 1733-1741.

Hartman, K.J., and Brandt, S.B. 1995. Estimating energy density of fish. Trans. Am. Fish. Soc. 124(3): 347-355.

Hartman, K.J., Margraf, F.J., Hafs, A.W., and Cox, M.K. 2015. Bioelectrical Impedance Analysis: A New Tool for Assessing Fish Condition. Fisheries 40(12): 590-600.

Hartman, K.J., Phelan, B.A., and Rosendale, J.E. 2011. Temperature effects on bioelectrical impedance analysis (BIA) used to estimate dry weight as a condition proxy in coastal bluefish. Mar. Coast. Fish. 3: 307-316.

Hayes, J.P., and Shonkwiler, J.S. 2001. Morphological indicators of body condition: useful or wishful thinking? In Body composition analysis of animals: a handbook of nondestructive methods. Edited by J.R. Speakman. Cambridge University Press, Cambridge, UK. pp. 8-38.

Henken, A.M., Lucas, H., Tijssen, P.A.T., and Machiels, M.A.M. 1986. A Comparison between Methods Used to Determine the Energy Content of Feed, Fish and Feces Samples. Aquaculture 58(3-4): 195-201.

Huntsberger, C.J., Hamlin, J.R., Smolowitz, R.J., and Smolowitz, R.M. 2017. Prevalence and 
description of Ichthyophonus sp in yellowtail flounder (Limanda ferruginea) from a seasonal survey on Georges Bank. Fish. Res. 194: 60-67.

Johnson, B.M., Pate, W.M., and Hansen, A.G. 2017. Energy Density and Dry Matter Content in Fish: New Observations and an Evaluation of Some Empirical Models. Trans. Am. Fish. Soc. 146(6): 1262-1278.

Kassambara, A., and Mundt, F. 2016. Factoextra: Extract and visualize the results of multivariate data analyses. https://CRAN.R-project.org/package=factoextra, $\mathrm{r}$ package version 1.0.3, 2016.

Klefoth, T., Skov, C., Aarestrup, K., and Arlinghaus, R. 2013. Reliability of non-lethal assessment methods of body composition and energetic status exemplified by applications to eel (Anguilla anguilla) and carp (Cyprinus carpio). Fish. Res. 146: 18-26.

Klein-MacPhee, G. 2002a. Righteye flounders, Family Pleuronectidae. In Bigelow and Shroeder's fishes of the Gulf of Maine. Edited by B.B. Collette and G. Klein-MacPhee. Smithsonian Institution. pp. 560-587.

Klein-MacPhee, G. 2002b. Sand flounders, Family Paralichthyidae. In Bigelow and Shroeder's fishes of the Gulf of Maine. Edited by B.B. Collette and G. Klein-MacPhee. Smithsonian Institution. pp. 551-560.

Lambert, Y., and Dutil, J.D. 1997. Condition and energy reserves of Atlantic cod (Gadus morhua) during the collapse of the northern Gulf of St. Lawrence stock. Can. J. Fish. Aquat. Sci. 54(10): 2388-2400.

Larsen, D.A., Middleton, M.A., Dickey, J.T., Gerstenberger, R.S., Brun, C.V., and Swanson, P. 2017. Use of Morphological and Physiological Indices to Characterize Life History Diversity in Juvenile Hatchery Winter-Run Steelhead. Trans. Am. Fish. Soc. 146(4): 663 - 
679.

853 Le Cren, E.D. 1951. The length-weight relationship and seasonal cycle in gonad weight and condition in the perch (Perca fluviatilis). J. Anim. Ecol. 20: 201-219.

855

856

857

858

859

860

861

862

863

864

865

866

867

868

869

870

871

872

873

874

Le, S., Josse, J., and Husson, F. 2008. FactoMineR: An R package for multivariate analysis. J. Stat. Softw. 25(1): 1-18.

Link, J.S., Bolles, K., and Milliken, C.G. 2002. The feeding ecology of flatfish in the northwest Atlantic. J. Northwest Atl. Fish. Sci. 30: 1-17.

Link, J.S., and Burnett, J. 2001. The relationship between stomach contents and maturity state for major northwest Atlantic fishes: new paradigms? J. Fish Biol. 59(4): 783-794.

Lleonart, J., Salat, J., and Torres, G.J. 2000. Removing allometric effects of body size in morphological analysis. J. Theor. Biol. 205(1): 85-93.

Love, R.M. 1980. The chemical biology of fishes: volume 2, advances 1968-1977 : with a supplementary key to the chemical literature. Academic Press, London ; New York.

MacCracken, J.G., and Stebbings, J.L. 2012. Test of a Body Condition Index with Amphibians. J. Herpetol. 46(3): 346-350.

Maceda-Veiga, A., Green, A.J., and De Sostoa, A. 2014. Scaled body-mass index shows how habitat quality influences the condition of four fish taxa in north-eastern Spain and provides a novel indicator of ecosystem health. Freshwater Biol. 59(6): 1145-1160.

Maddock, D.M., and Burton, M.P.M. 1994. Some effects of starvation on the lipid and skeletal muscle layers of the winter flounder, Pleuronectes americanus. Can. J. Zool 72: 16721679.

Marshall, C.T., Needle, C.L., Thorsen, A., Kjesbu, O.S., and Yaragina, N.A. 2006. Systematic bias in estimates of reproductive potential of an Atlantic cod (Gadus morhua) stock: 
implications for stock-recruit theory and management. Can. J. Fish. Aquat. Sci. 63(5): 980-994.

Marshall, C.T., Needle, C.L., Yaragina, N.A., Ajiad, A.M., and Gusev, E. 2004. Deriving condition indices from standard fisheries databases and evaluating their sensitivity to variation in stored energy reserves. Can. J. Fish. Aquat. Sci. 61(10): 1900-1917.

Marshall, C.T., O'Brien, L., Tomkiewicz, J., Koster, F.W., Kraus, G., Marteinsdottir, G., Morgan, M.J., Saborido-Rey, F., Blanchard, J.L., Secor, D.H., Wright, P.J., Mukhina, N.V., and Bjornsson, H. 2003. Developing alternative indices of reproductive potential for use in fisheries management: case studies for stocks spanning an information gradient. J. Northwest Atl. Fish. Sci. 33: 161-190.

Marshall, C.T., Yaragina, N.A., Lambert, Y., and Kjesbu, O.S. 1999. Total lipid energy as a proxy for total egg production by fish stocks. Nature 402: 288-290.

Masse, J., Sanchez, F., Delaunay, D., Robert, J.M., and Petitgas, P. 2016. A partnership between science and industry for a monitoring of anchovy \& sardine in the Bay of Biscay: When fishermen are actors of science. Fish. Res. 178: 26-38.

McBride, R.S., Somarakis, S., Fitzhugh, G.R., Albert, A., Yaragina, N.A., Wuenschel, M.J., Alonso-Fernandez, A., and Basilone, G. 2015. Energy acquisition and allocation to egg production in relation to fish reproductive strategies. Fish Fish. 16(1): 23-57.

McBride, R.S., Wuenschel, M.J., Nitschke, P., Thornton, G., and King, J.R. 2013. Latitudinal and stock-specific variation in size- and age-at-maturity of female winter flounder, Pseudopleuronectes americanus, as determined with gonad histology. J. Sea Res. 75: 4151.

McElroy, W.D., Wuenschel, M.J., Press, Y.K., Towle, E.K., and McBride, R.S. 2013. 
Differences in female individual reproductive potential among three stocks of winter flounder, Pseudopleuronectes americanus. J. Sea Res. 75: 52-61.

McElroy, W.D., Wuenschel, M.J., Towle, E.K., and McBride, R.S. 2016. Spatial and annual variation in fecundity and oocyte atresia of yellowtail flounder, Limanda ferruginea, in US waters. J. Sea Res. 107(1): 76-89.

McPherson, L.R., Slotte, A., Kvamme, C., Meier, S., and Marshall, C.T. 2011. Inconsistencies in measurement of fish condition: a comparison of four indices of fat reserves for Atlantic herring (Clupea harengus). ICES J. Mar. Sci. 68(1): 52-60.

Merson, R.R., Casey, C.S., Martinez, C., Soffientino, B., Chandlee, M., and Specker, J.L. 2000. Oocyte development in summer flounder: seasonal changes and steroid correlates. J. Fish Biol. 57(1): 182-196.

Morgan, M.J., Koen-Alonso, M., Rideout, R.M., Buren, A.D., and Parsons, D.M. 2018. Growth and condition in relation to the lack of recovery of northern cod. ICES J. Mar. Sci. 75(2): 631-641.

Morita, S.H., Morita, K., Hamatsu, T., Chimura, M., Yamashita, Y., Sasaki, K., and Sato, T. 2015. Differential effects of the environment on the growth of arabesque greenling (Pleurogrammus azonus): does rising temperature benefit young but not old fish? Environ. Biol. Fish 98(3): 801-809.

Morley, J.W., Buckel, J.A., and Lankford, T.E. 2012. Comparing Multiple Predictors of Energy Content in Juvenile Bluefish. Trans. Am. Fish. Soc. 141(4): 1109-1116.

Nash, R.D.M., Valencia, A.H., and Geffen, A.J. 2006. The origin of Fulton's condition factor Setting the record straight. Fisheries 31(5): 236-238.

Northeast Fisheries Science Center. 2017. Operational assessment of 19 Northeast Groundfish 
Stocks, Updated through 2016. US Dept Commer, Northeast Fish Sci Cent Ref Doc. 1717. 259 p. doi:210.7289/V7285/RD-NEFSC-17-17.

O'Brien, L., Burnett, J., and Mayo, R.K. 1993. Maturation of nineteen species of finfish off the Northeast coast of the United States, 1985-1990. NOAA Tech. Rep. NMFS 113. p. 66.

Peig, J., and Green, A.J. 2009. New perspectives for estimating body condition from mass/length data: the scaled mass index as an alternative method. Oikos 118(12): 1883-1891.

Peig, J., and Green, A.J. 2010. The paradigm of body condition: a critical reappraisal of current methods based on mass and length. Funct. Ecol. 24(6): 1323-1332.

Plante, S., Audet, C., Lambert, Y., and De La Noue, J. 2005. Alternative methods for measuring energy content in winter flounder. N. Am. J. Fish. Manage. 25(1): 1-6.

Pothoven, S.A., Ludsin, S.A., Hook, T.O., Fanslow, D.L., Mason, D.M., Collingsworth, P.D., and Van Tassell, J.J. 2008. Reliability of bioelectrical impedance analysis for estimating whole-fish energy density and percent lipids. Trans. Am. Fish. Soc. 137(5): 1519-1529.

Press, Y.K., McBride, R.S., and Wuenschel, M.J. 2014. Time course of oocyte development in winter flounder Pseudopleuronectes americanus and spawning seasonality for the Gulf of Maine, Georges Bank and southern New England stocks. J. Fish. Biol. 85(2): 421-445.

Rasmussen, J.B., Krimmer, A.N., Paul, A.J., and Hontela, A. 2012. Empirical relationships between body tissue composition and bioelectrical impedance of brook trout Salvelinus fontinalis from a Rocky Mountain Stream. J. Fish Biol. 80(6): 2317-2327.

Renkawitz, M.D., Sheehan, T.F., Dixon, H.J., and Nygaard, R. 2015. Changing trophic structure and energy dynamics in the Northwest Atlantic: implications for Atlantic salmon feeding at West Greenland. Mar. Ecol. Prog. Ser. 538: 197-211.

Ricker, W.E. 1975. Computation and interpretation of biological statistics of fish populations. 
Bull. Fish. Res. Board Can. No. 191.

945

946

947

948

949

950

951

952

953

954

955

956

957

958

959

960

961

962

963

964

965

966

Robards, M.D., Anthony, J.A., Rose, G.A., and Piatt, J.F. 1999. Changes in proximate composition and somatic energy content for Pacific sand lance (Ammodytes hexapterus) from Kachemak Bay, Alaska relative to maturity and season. J. Exp. Mar. Biol. Ecol. 242: $245-258$.

Robins, C.R., and Ray, G.C. 1986. A field guide to Atlantic Coast fishes of North America. Houghton Mifflin, Boston.

Sardenne, F., Chassot, E., Fouche, E., Menard, F., Lucas, V., and Bodin, N. 2016. Are condition factors powerful proxies of energy content in wild tropical tunas? Ecol. Indic. 71: 467476.

Schloesser, R.W., and Fabrizio, M.C. 2015. Relationships among Proximate Components and Energy Density of Juvenile Atlantic Estuarine Fishes. Trans. Am. Fish. Soc. 144(5): 942955.

Schloesser, R.W., and Fabrizio, M.C. 2017. Condition indices as surrogates of energy density and lipid content in juveniles of three fish species. Trans. Am. Fish. Soc. 146(5): 10581069.

Schreckenbach, K., Knosche, R., and Ebert, K. 2001. Nutrient and energy content of freshwater fishes. J. Appl. Ichthyol. 17(3): 142-144.

Scott, I., Selman, C., Mitchell, P.I., and Evans, P. 2001. The use of total body electrical conductivity (TOBEC) to determine body composition in vertebrates. In Body composition analysis of animals: a handbook of non-destructive methods. Edited by J.R. Speakman. Cambridge University Press, Cambridge, UK. pp. 127-160.

Shulman, G.E., and Love, R.M. 1999. Advances in marine biology - The biochemical ecology of 
marine fishes - Introduction. Adv. Mar. Biol. 36: 1-351.

Smith, B.E., and Link, J.S. 2010. The Trophic Dynamics of 50 Finfish and 2 Squid Species on the Northeast US Continental Shelf. NOAA Tech. Memo. NMFS NE 216. Available from: National Marine Fisheries Service, 166 Water Street, Woods Hole, MA 025431026, or online at http://www.nefsc.noaa.gov/nefsc/publications/. p. 640.

Smith, C., and Wootton, R.J. 2016. The remarkable reproductive diversity of teleost fishes. Fish Fish. 17(4): 1208-1215.

Stevenson, R.D., and Woods, W.A. 2006. Condition indices for conservation: new uses for evolving tools. Integr. Comp. Biol. 46(6): 1169-1190.

Stolarski, J.T., Margraf, F.J., Carlson, J.G., and Sutton, T.M. 2014. Lipid and Moisture Content Modeling of Amphidromous Dolly Varden Using Bioelectrical Impedance Analysis. N. Am. J. Fish. Manage. 34(3): 471-481.

Vidacek, S., Medic, H., Botka-Petrak, K., Nezak, J., and Petrak, T. 2008. Bioelectrical impedance analysis of frozen sea bass (Dicentrarchus labrax). J. Food Eng. 88(2): 263271.

Vidacek, S., Medic, H., Marusic, N., Tonkovic, S., and Petrak, T. 2012. Influence of Different Freezing Regimes on Bioelectrical Properties of Atlantic Chub Mackerel (Scomber Colias). J. Food Process Eng. 35(5): 735-741.

Wei, T., and Simko, V. 2016. corrplot: visualization of a correlation Matrix. R package version 0.77. https://CRAN.R-project.org/package=corrplot.

Winton, M.V., Wuenschel, M.J., and McBride, R.S. 2014. Investigating spatial variation and temperature effects on maturity of female winter flounder (Pseudopleuronectes americanus) using generalized additive models. Can. J. Fish. Aquat. Sci. 71(9): 1279- 

1290.

991 Wootton, R.J. 1990. Ecology of teleost fishes. Chapman and Hall, London.

992 Wuenschel, M.J., Able, K.W., and Byrne, D. 2009. Seasonal patterns of winter flounder

993 Pseudopleuronectes americanus abundance and reproductive condition on the New York 994 Bight continental shelf. J. Fish Biol. 74(7): 1508-1524.

995 Wuenschel, M.J., Able, K.W., Vasslides, J.M., and Byrne, D.M. 2013a. Habitat and diet overlap 996 of 4 piscivorous fishes: variation on the inner continental shelf off New Jersey. Fish. Bull. 111(4): 352-369.

998 999

1000 1001 1002 1003 1004 1005 1006 1007 1008 
1 Table 1. Summary of life history characteristics for the three flatfishes studied.

\begin{tabular}{|c|c|c|c|}
\hline & Winter flounder & Yellowtail flounder & $\begin{array}{l}\text { Summer } \\
\text { flounder }\end{array}$ \\
\hline Spawning pattern & Total spawner & Batch spawner & Batch spawner \\
\hline Spawning location & Estuaries and Ocean & Ocean & Ocean \\
\hline Oocyte development & Group synchronous & Group synchronous & Asynchronous \\
\hline Egg type & Benthic & Pelagic & Pelagic \\
\hline Fecundity type & Determinate & Determinate & Indeterminate \\
\hline Feeding & Benthivore & Benthivore & Piscivore \\
\hline $\begin{array}{l}\text { Energy allocation for } \\
\text { reproduction * }\end{array}$ & Capital & Capital & Income-Capital \\
\hline Feeding vs. reproduction $\dagger$ & Rester & Rester & Indeterminate \\
\hline $\begin{array}{l}\text { Median size }\left(\mathrm{L}_{50} ; \mathrm{cm}\right) \text { at } \\
\text { maturity }+\end{array}$ & $\begin{array}{l}\text { SNE: M } 29 \text { F } 30 \\
\text { GOM: M } 28 \text { F } 26 \\
\text { GB: M } 26 \text { F } 34\end{array}$ & $\begin{array}{l}\text { SNE: M } 20 \text { F } 26 \\
\text { GOM: M } 27 \text { F } 27 \\
\text { GB: M } 21 \text { F } 26\end{array}$ & M 25 F 28 \\
\hline $\begin{array}{l}\text { Median age }\left(\mathrm{A}_{50} ; \mathrm{yrs}\right) \text { at } \\
\text { maturity }+\end{array}$ & $\begin{array}{l}\text { SNE: M } 3.3 \text { F } 2.6 \\
\text { GOM: M } 3.3 \text { F } 3.9 \\
\text { GB: M } 1.9 \text { F } 3.1\end{array}$ & $\begin{array}{l}\text { SNE: M } 1.8 \text { F } 1.6 \\
\text { GOM: M } 2.6 \text { F } 2.6 \\
\text { GB: M } 1.3 \text { F } 1.8\end{array}$ & M 2 F 2.5 \\
\hline Maximum size $\S$ and age\| & $\begin{array}{l}64 \mathrm{~cm} \\
3.6 \mathrm{~kg} \\
15 \mathrm{yr}\end{array}$ & $\begin{array}{l}64 \mathrm{~cm} \\
1.5 \mathrm{~kg} \\
17 \mathrm{yr}\end{array}$ & $\begin{array}{l}94 \mathrm{~cm} \\
12 \mathrm{~kg} \\
12 \mathrm{yr}\end{array}$ \\
\hline Seasonal movements \| & $\begin{array}{l}\text { Limited } \\
\text { (10's of km) }\end{array}$ & $\begin{array}{l}\text { Limited } \\
(10 \text { 's of km) }\end{array}$ & $\begin{array}{l}\text { Extensive } \\
(100 \text { 's of km) }\end{array}$ \\
\hline
\end{tabular}

2 Note: Stock regions (Georges Bank, GB; Gulf of Maine GOM; Southern New England, SNE)

3 and sex (Female, F; Male, M).

$4 *$ sensu McBride et al. (2015) 
$5 \uparrow$ sensu Link and Burnett (2001)

$6 \$$ Winton et al. (2014), O’Brien et al. (1993)

$7 \S$ Robins and Ray 1986

8 || Klein-MacPhee 2002a, $b$

9

10

11 
Table 2. Summary of numbers and sizes of fish examined for the present analysis. (CP= Northeast Fisheries Science Center (NEFSC) Cooperative Research Branch (CRB) gear study, SF= CRB Study Fleet, BG=NEFSC Ecosystems Surveys Branch bottom trawl survey, MA = Massachusetts Department of Fish and Game Division of Marine Fisheries bottom trawl survey, RI= University of Rhode Island Graduate School of Oceanography bottom trawl survey). Totals (within each year and across all years) are indicated in bold. * indicates mean values used as $L_{0}$ in calculation of $S M I$.

\begin{tabular}{|c|c|c|c|c|c|c|c|c|c|c|}
\hline & & & Winter flounder & & & Yellowtail flounder & & & Summer flounder & \\
\hline Year & Source & $\mathbf{N}$ & $\begin{array}{l}\text { Mean TL(min- } \\
\text { max) }\end{array}$ & $\begin{array}{l}\text { Months } \\
\text { sampled }\end{array}$ & $\mathbf{N}$ & Mean TL(min-max) & $\begin{array}{c}\text { Months } \\
\text { sampled }\end{array}$ & $\mathbf{N}$ & $\begin{array}{c}\text { Mean TL(min- } \\
\text { max) }\end{array}$ & $\begin{array}{l}\text { Months } \\
\text { sampled }\end{array}$ \\
\hline \multirow[t]{3}{*}{2009} & $\mathrm{CP}$ & 63 & $324.5(226-485)$ & 12 & 20 & $299.2(237-348)$ & 12 & 32 & $424.8(232-679)$ & 12 \\
\hline & SF & 13 & $347.8(312-401)$ & 12 & 44 & $376.5(332-432)$ & 12 & 29 & $439.3(384-591)$ & 12 \\
\hline & & 76 & $328.5(226-485)$ & 12 & 64 & $352.3(237-432)$ & 12 & 61 & $431.7(232-679)$ & 12 \\
\hline \multirow[t]{6}{*}{2010} & BG & 10 & $336.1(215-426)$ & 10 & 31 & $379.1(277-432)$ & 10 & 2 & $457.0(454-460)$ & 10 \\
\hline & $\mathrm{CP}$ & 148 & $351.1(155-548)$ & $3,4,10,11$ & 157 & $327.1(202-443)$ & $3,4,10,11$ & 23 & $426.0(256-668)$ & 4 \\
\hline & MA & 75 & $210.1(90-398)$ & 5,9 & 31 & $309.5(210-383)$ & 5,9 & 15 & $317.5(216-353)$ & 9 \\
\hline & RI & 43 & $243.3(90-372)$ & $1-4$ & & & & 7 & $314.3(290-337)$ & 8 \\
\hline & SF & 674 & $335.6(155-525)$ & $1-3,5-12$ & 693 & $366.8(232-487)$ & $1-3,5-12$ & 376 & $491.1(242-736)$ & $1-3,5-12$ \\
\hline & & 950 & $324.0(90-548)$ & 1-12, & 912 & $358.5(202-487)$ & 1-12, & 423 & $478.3(216-736)$ & $1-12$ \\
\hline \multirow[t]{3}{*}{2011} & MA & 101 & $256.1(76-441)$ & 5 & 86 & $299.4(118-426)$ & 5 & 3 & $271.0(257-283)$ & 5 \\
\hline & $\mathrm{SF}$ & 348 & $361.6(220-523)$ & $1-5$ & 431 & $366.3(240-475)$ & $1-6$ & 513 & $469.5(295-730)$ & $1-5,9-11$ \\
\hline & & 449 & $337.9(76-523)$ & $1-5$ & 517 & $355.1(118-475)$ & $1-6$ & 516 & $468.3(257-730)$ & $1-5,9-11$ \\
\hline \multirow[t]{3}{*}{2012} & MA & 125 & $297.0(137-452)$ & 5 & 7 & $350.0(314-433)$ & 5 & & & \\
\hline & SF & 268 & $374.9(281-490)$ & $1-5$ & 270 & $368.7(317-464)$ & $3-5$ & 399 & $496.6(361-723)$ & $3-4,9-11$ \\
\hline & & 393 & $350.1(137-490)$ & $1-5$ & 277 & $368.2(314-464)$ & $3-5$ & 399 & $496.6(361-723)$ & $3-4,9-11$ \\
\hline \multirow[t]{3}{*}{2013} & MA & 37 & $207.2(101-349)$ & 5 & 19 & $317.6(219-427)$ & 5 & & & \\
\hline & $\mathrm{SF}$ & 260 & $375.9(291-491)$ & $1-5$ & 379 & $368.6(319-448)$ & $3-5$ & 87 & $516.3(374-718)$ & $3-4$ \\
\hline & & 297 & $354.9(101-491)$ & $1-5$ & 398 & $366.1(219-448)$ & $3-5$ & 87 & $516.3(374-718)$ & $3-4$ \\
\hline \multirow[t]{2}{*}{2014} & $\mathrm{SF}$ & 267 & $369.5(295-493)$ & $1-4$ & 289 & $373.5(304-457)$ & $3-6$ & & & \\
\hline & & 267 & $369.5(295-493)$ & $1-4$ & 289 & $373.5(304-457)$ & $3-6$ & & & \\
\hline \multirow[t]{2}{*}{2015} & SF & 179 & $363.4(281-461)$ & $1-4$ & 389 & $377.4(307-462)$ & $2-5$ & & & \\
\hline & & 179 & $363.4(281-461)$ & $1-4$ & 389 & $377.4(307-462)$ & $2-5$ & & & \\
\hline \multirow[t]{2}{*}{2016} & SF & 239 & $366.9(296-469)$ & $1-4$ & 306 & $365.6(299-502)$ & $2-5$ & & & \\
\hline & & 239 & $366.9(296-469)$ & $1-4$ & 306 & $365.6(299-502)$ & $2-5$ & & & \\
\hline ALL & & 2850 & $343.4 *(76-548)$ & & 3152 & $364.0 *(118-502)$ & & 1486 & $480.0 *(216-736)$ & \\
\hline
\end{tabular}


17 Table 3. Summary of biological variables, morphometric indices, bioelectrical, and biochemical 18 variables analyzed. Units for each measure are indicated in parentheses if not unitless.

\begin{tabular}{|c|c|c|}
\hline Measure & Abbreviation & Equation \\
\hline \multicolumn{3}{|l|}{ Biological variables } \\
\hline Total length (mm) & TLENGTH & Measured in $\mathrm{mm}$ \\
\hline Total weight (g) & TWEIGHT & Measured in g \\
\hline Gonad Free Fish Weight (g) & GFWEIGHT & TWEIGHT - GWEIGHT \\
\hline Gonad Weight (g) & GWEIGHT & Measured in $\mathrm{g}$ \\
\hline Liver Weight (g) & LWEIGHT & Measured in $\mathrm{g}$ \\
\hline Gonadosomatic Index & GSI & $100 \bullet($ GWEIGHT / (TWEIGHT - GWEIGHT)) \\
\hline Hepatosomatic Index & $\mathrm{HSI}$ & $100 \bullet($ LWEIGHT / (TWEIGHT - LWEIGHT)) \\
\hline \multicolumn{3}{|l|}{ Morphometric Condition Index } \\
\hline Fulton's K & $\mathrm{K}$ & 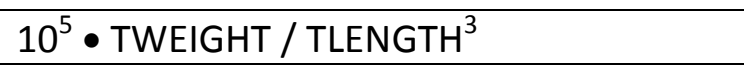 \\
\hline Relative Condition & $\mathrm{Kn}$ & TWEIGHT / predicted mass \\
\hline Scaled Mass Index & SMI & $M_{i}\left[\frac{L_{0}}{L_{i}}\right]^{b_{S M A}}$ \\
\hline \multicolumn{3}{|l|}{$\begin{array}{l}\text { Bioelectrical Impedance } \\
\text { Analysis }\end{array}$} \\
\hline Resistance (ohms) & RESIS & Measured by Quantum X \\
\hline Reactance (ohms) & REACT & Measured by Quantum X \\
\hline Resistance in series (ohms) & RS & $\mathrm{DL}^{2} / \mathrm{RESIS}$ \\
\hline Reactance in series (ohms) & $\mathrm{XC}$ & $\mathrm{DL}^{2} / \mathrm{REACT}$ \\
\hline Resistance in parallel (ohms) & $\mathrm{RP}$ & $\mathrm{DL}^{2} /\left[\mathrm{RESIS}+\left(\mathrm{REACT}^{2} / \mathrm{RESIS}\right)\right]$ \\
\hline Reactance in Parallel (ohms) & XCP & $\mathrm{DL}^{2} /\left[\mathrm{REACT}+\left(\mathrm{RESIS}^{2} / \mathrm{REACT}\right)\right]$ \\
\hline Capacitance (Picofarads) & CPF & $\mathrm{DL}^{2} /\left\{[1 /(2 \bullet \pi \bullet 50000 \bullet \operatorname{RESIS})]\left[1 \bullet 10^{12}\right]\right\}$ \\
\hline Impedance in series (ohms) & ZS & $\mathrm{DL}^{2} /\left(\mathrm{RESIS}^{2}+\mathrm{REACT}^{2}\right)^{0.5}$ \\
\hline Impedance in parallel (ohms) & $\mathrm{ZP}$ & $\mathrm{DL}^{2} /\left[\mathrm{RESIS} \bullet \mathrm{REACT} /\left(\mathrm{RESIS}^{2}+\mathrm{REACT}^{2}\right)^{0.5}\right]$ \\
\hline Phase Angle (degrees) & PA & $\operatorname{Arctan}(\operatorname{REACT} / \mathrm{RESIS}) \bullet 180 / \pi$ \\
\hline $\begin{array}{l}\text { Standardized Phase Angle } \\
\text { (degrees) }\end{array}$ & PADL & $\mathrm{DL} \bullet[\operatorname{Arctan}(\mathrm{REACT} / \mathrm{RESIS}) \bullet 180 / \pi]$ \\
\hline Body Mass Index (ohms) & BMI & $\left\{\left[\left(\mathrm{RESIS}^{2}+\mathrm{REACT}^{2}\right)^{0.5}\right] \bullet \mathrm{TWEIGHT}\right\} / \mathrm{DL}^{2}$ \\
\hline \multicolumn{3}{|l|}{ Biochemical } \\
\hline Percent Dry Weight of Muscle & \%DWM & $100 \bullet($ dry mass / wet mass $)$ \\
\hline Percent Dry Weight of Liver & $\% \mathrm{DWL}$ & $100 \bullet($ dry mass / wet mass $)$ \\
\hline Total Liver Energy $(\mathrm{kJ})$ & TLE & LWEIGHT • Liver energy density \\
\hline
\end{tabular}


Table 4. Summary of non-linear regression models to determine parameters for calculation of Kn and standardized major axis regression model for parametrization of SMI. In parentheses are standard error for Kn parameter estimates and 95\% C.I. for SMI parameter estimates.

\begin{tabular}{|l|l|l|l|l|l|}
\hline & & Intercept & Slope & & \\
\hline Kn & $\mathrm{n}$ & $\mathrm{a}$ & $\mathrm{b}$ & & \\
\hline Winter flounder & 1732 & $\begin{array}{l}1.340 \times 10^{-5} \\
\left(1.393 \times 10^{-6}\right)\end{array}$ & $\begin{array}{l}2.989 \\
\left(1.726 \times 10^{-2}\right)\end{array}$ & & \\
\hline Yellowtail flounder & 1522 & $\begin{array}{l}2.749 \times 10^{-6} \\
\left(4.746 \times 10^{-7}\right)\end{array}$ & $3.192\left(2.895 \times 10^{-2}\right)$ & & \\
\hline Summer flounder & 1079 & $\begin{array}{l}1.776 \times 10^{-6} \\
\left(1.758 \times 10^{-7}\right)\end{array}$ & $\begin{array}{l}3.286 \\
\left(1.544 \times 10^{-2}\right)\end{array}$ & & \\
\hline & & & & & \\
\hline SMI & & Intercept & $b_{S M A}$ & $\mathrm{~L}_{0}$ & $\boldsymbol{r}^{2}$ \\
\hline Winter flounder & 1732 & $\begin{array}{l}-11.738 \\
(-11.846,-11.630)\end{array}$ & $\begin{array}{l}3.0765 \\
(3.0578,3.0952)\end{array}$ & 343.4 & 0.983 \\
\hline Yellowtail flounder & 1522 & -12.928 & 3.2127 & 364.0 & 0.943 \\
& & $(-13.155,-12.704)$ & $(3.1745,3.2514)$ & & \\
\hline Summer flounder & 1079 & -12.955 & 3.2402 & 480.0 & 0.989 \\
& & $(-13.082,-12.829)$ & $(3.2197,3.2609)$ & & \\
\hline
\end{tabular}

25

26

27

28

29

Table 5. Results of linear regressions for tissue energy density (liver or muscle) as a function of tissue percent dry weight $(\% \mathrm{DWL}$ or $\% \mathrm{DWM})$. Estimates of parameters listed with std. error in parentheses.

\begin{tabular}{|l|c|c|c|c|c|}
\hline & $\mathbf{n}$ & Intercept & Slope & Adj. $\boldsymbol{r}^{\mathbf{2}}$ & Prob(>|t|) \\
\hline Liver Energy Density & & & & & \\
\hline Winter flounder & 50 & $\begin{array}{c}-4.67 \\
(0.346)\end{array}$ & $\begin{array}{c}0.402 \\
(0.0112)\end{array}$ & 0.963 & $<0.001$ \\
\hline Yellowtail flounder & 42 & $\begin{array}{c}-3.36 \\
(0.341)\end{array}$ & $\begin{array}{c}0.372 \\
(0.0116)\end{array}$ & 0.962 & $<0.001$ \\
\hline Summer flounder & 43 & $\begin{array}{c}-3.54 \\
(0.297)\end{array}$ & $\begin{array}{c}0.375 \\
(0.00816)\end{array}$ & 0.981 & $<0.001$ \\
\hline & & & & & \\
\hline Muscle Energy Density & & & & & \\
\hline Winter flounder & 46 & $\begin{array}{c}-0.294 \\
(0.0728)\end{array}$ & $\begin{array}{c}0.207 \\
(0.00364)\end{array}$ & \\
\hline Yellowtail flounder & 40 & $\begin{array}{c}-0.156 \\
(0.0872)\end{array}$ & $\begin{array}{c}0.201 \\
(0.00450)\end{array}$ & 0.986 & $<0.001$ \\
\hline Summer flounder & 45 & $\begin{array}{c}-0.167 \\
(0.107)\end{array}$ & $\begin{array}{c}0.201 \\
(0.00497)\end{array}$ & 0.974 & $<0.001$ \\
\hline
\end{tabular}


30 Table 6. Summary of significant variable loadings for the first four principle components for each species. Correlations greater than 0.6 are indicated 31 in bold. The qualitative variables listed are not included in forming the principal components, but how they relate to each PC is tested post-hoc.

32 Sample sizes for complete cases used in each analysis is indicated. (* indicates $0.001<\mathrm{p}<0.05$, all else p $<0.001$ )

\begin{tabular}{|c|c|c|c|c|c|c|c|c|c|c|c|c|}
\hline \multirow[b]{2}{*}{$\overline{\mathrm{PC}}$} & \multicolumn{4}{|c|}{ Winter flounder $\mathrm{n}=1294$} & \multicolumn{4}{|c|}{ Yellowtail flounder $\mathrm{n}=1571$} & \multicolumn{4}{|c|}{ Summer flounder $\mathrm{n}=780$} \\
\hline & 1 & 2 & 3 & 4 & 1 & 2 & 3 & 4 & 1 & 2 & 3 & 4 \\
\hline$\%$ exp. Var. & 48.7 & 17.6 & 10.8 & 7.2 & 42.1 & 23.8 & 10.8 & 7.9 & 57.2 & 13.3 & 7.9 & 5.7 \\
\hline Variable & corr. & corr. & corr. & corr. & corr. & corr. & corr. & corr. & corr. & corr. & corr. & corr. \\
\hline $\mathrm{K}$ & 0.21 & 0.85 & -0.36 & $-0.10 *$ & 0.38 & 0.74 & -0.42 & -0.25 & 0.65 & 0.60 & -0.27 & $-0.08 *$ \\
\hline $\mathrm{Kn}$ & 0.22 & 0.85 & -0.36 & $-0.10 *$ & 0.23 & 0.74 & -0.49 & -0.27 & & 0.79 & -0.38 & \\
\hline SMI & -0.14 & 0.83 & -0.43 & $-0.08 *$ & 0.15 & 0.74 & -0.51 & -0.28 & -0.64 & 0.61 & -0.33 & \\
\hline TLENGTH & 0.92 & -0.12 & 0.25 & & 0.86 & & 0.39 & 0.14 & 0.97 & $-0.13^{*}$ & $0.10^{*}$ & $-0.08 *$ \\
\hline TWEIGHT & 0.95 & $0.10^{*}$ & 0.16 & & 0.92 & 0.23 & 0.20 & $0.06^{*}$ & 0.98 & & $0.08 *$ & $-0.09 *$ \\
\hline GFWEIGHT & 0.93 & & 0.21 & 0.12 & 0.90 & 0.14 & 0.23 & 0.22 & 0.98 & & $0.07 *$ & $-0.11 *$ \\
\hline GWEIGHT & 0.72 & 0.31 & & -0.49 & 0.64 & 0.45 & $0.05^{*}$ & -0.47 & 0.72 & $0.10^{*}$ & 0.15 & 0.59 \\
\hline LWEIGHT & 0.87 & 0.33 & $0.09 *$ & & 0.82 & 0.41 & $-0.06^{*}$ & 0.17 & 0.91 & 0.24 & & $0.11 *$ \\
\hline GSI & 0.48 & 0.36 & -0.12 & -0.65 & 0.43 & 0.47 & & -0.60 & 0.40 & $0.12 *$ & $0.12 *$ & 0.85 \\
\hline HSI & 0.46 & 0.48 & $-0.08^{*}$ & $0.09 *$ & 0.51 & 0.48 & -0.31 & 0.17 & 0.43 & 0.55 & & 0.32 \\
\hline RESIS & -0.52 & $0.11 *$ & 0.47 & & -0.61 & 0.28 & 0.23 & 0.25 & -0.70 & $0.09 *$ & 0.29 & \\
\hline REACT & -0.54 & 0.35 & 0.70 & & -0.58 & 0.59 & 0.41 & 0.12 & -0.62 & 0.35 & 0.61 & $-0.07 *$ \\
\hline $\mathrm{RS}$ & 0.97 & -0.16 & & $0.07 *$ & 0.95 & -0.21 & 0.15 & & 0.97 & $-0.14 *$ & & \\
\hline $\mathrm{XC}$ & 0.89 & -0.30 & -0.21 & $0.06^{*}$ & 0.68 & -0.53 & -0.26 & $0.05^{*}$ & 0.90 & -0.28 & -0.20 & \\
\hline $\mathrm{RP}$ & 0.97 & -0.19 & & $0.06^{*}$ & 0.94 & -0.26 & 0.11 & & 0.97 & -0.17 & & \\
\hline $\mathrm{XCP}$ & 0.89 & & 0.31 & $0.07 *$ & 0.69 & 0.35 & 0.54 & $-0.06^{*}$ & 0.94 & & 0.24 & $-0.10 *$ \\
\hline $\mathrm{CPF}$ & 0.97 & -0.16 & & $0.07 *$ & 0.95 & -0.21 & 0.15 & & 0.97 & $-0.14 *$ & & \\
\hline $\mathrm{ZS}$ & 0.97 & -0.18 & & $0.06^{*}$ & 0.95 & -0.23 & 0.13 & & 0.97 & -0.16 & & \\
\hline $\mathrm{ZP}$ & 0.90 & -0.30 & -0.20 & $0.06^{*}$ & 0.69 & -0.53 & -0.25 & $0.05^{*}$ & 0.91 & -0.27 & -0.18 & \\
\hline PA & -0.36 & 0.48 & 0.66 & & -0.40 & 0.70 & 0.47 & & -0.21 & 0.53 & 0.72 & $-0.13 *$ \\
\hline PADL & 0.44 & 0.29 & 0.77 & $0.06^{*}$ & & 0.68 & 0.68 & & 0.69 & 0.21 & 0.59 & $-0.14 *$ \\
\hline BMI & $0.06 *$ & 0.58 & 0.34 & -0.24 & -0.19 & 0.77 & $0.09 *$ & 0.12 & 0.45 & 0.40 & 0.19 & $-0.12 *$ \\
\hline \%DWM & -0.20 & 0.47 & -0.15 & 0.69 & $-0.06^{*}$ & 0.44 & -0.37 & 0.53 & 0.37 & 0.55 & -0.20 & \\
\hline \%DWL & 0.14 & 0.48 & -0.15 & 0.68 & 0.19 & 0.41 & -0.31 & 0.68 & 0.44 & 0.53 & -0.22 & -0.34 \\
\hline TLE & 0.79 & 0.40 & $0.06^{*}$ & 0.25 & 0.67 & 0.43 & -0.17 & 0.47 & 0.84 & 0.35 & & \\
\hline
\end{tabular}


34 Table 6 continued.

\begin{tabular}{|l|c|c|c|c|c|c|c|c|c|c|c|c|}
\hline & \multicolumn{4}{|l|}{ Winter flounder $\mathrm{n}=1294$} & \multicolumn{2}{l|}{ Yellowtail flounder $\mathrm{n}=1571$} & \multicolumn{2}{l|}{ Summer flounder $\mathrm{n}=780$} \\
\hline PC & 1 & 2 & 3 & 4 & 1 & 2 & 3 & 4 & 1 & 2 & 3 & 4 \\
\hline \% exp. Var. & 48.7 & 17.6 & 10.8 & 7.2 & 42.1 & 23.8 & 10.8 & 7.9 & 57.2 & 13.3 & 7.9 & 5.7 \\
\hline Qual. Factors & $r^{2}$ & $r^{2}$ & $r^{2}$ & $r^{2}$ & $r^{2}$ & $r^{2}$ & $r^{2}$ & $r^{2}$ & $r^{2}$ & $r^{2}$ & $r^{2}$ & $r^{2}$ \\
\hline REPPHASE & 0.21 & 0.30 & 0.06 & 0.17 & 0.09 & 0.16 & 0.06 & 0.15 & 0.24 & $0.02^{*}$ & & 0.52 \\
\hline SEX & 0.07 & $0.01^{*}$ & & 0.02 & 0.11 & $0.01 *$ & & 0.02 & 0.07 & & & $0.01^{*}$ \\
\hline STOCK & 0.09 & & 0.08 & 0.08 & 0.12 & 0.27 & $0.01^{*}$ & 0.04 & - & - & - & - \\
\hline
\end{tabular}




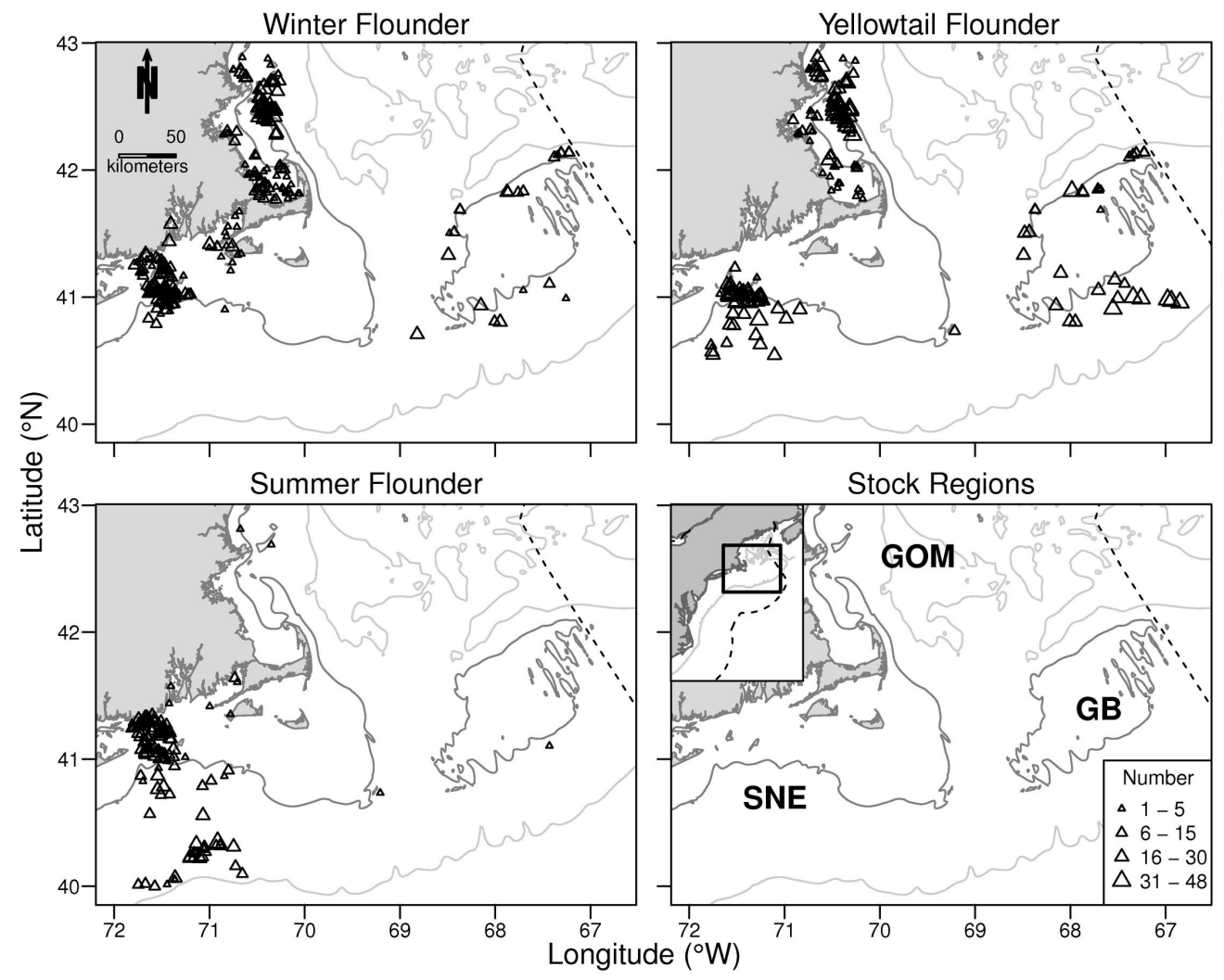

Fig. 1

$190 \times 152 \mathrm{~mm}(300 \times 300 \mathrm{DPI})$ 


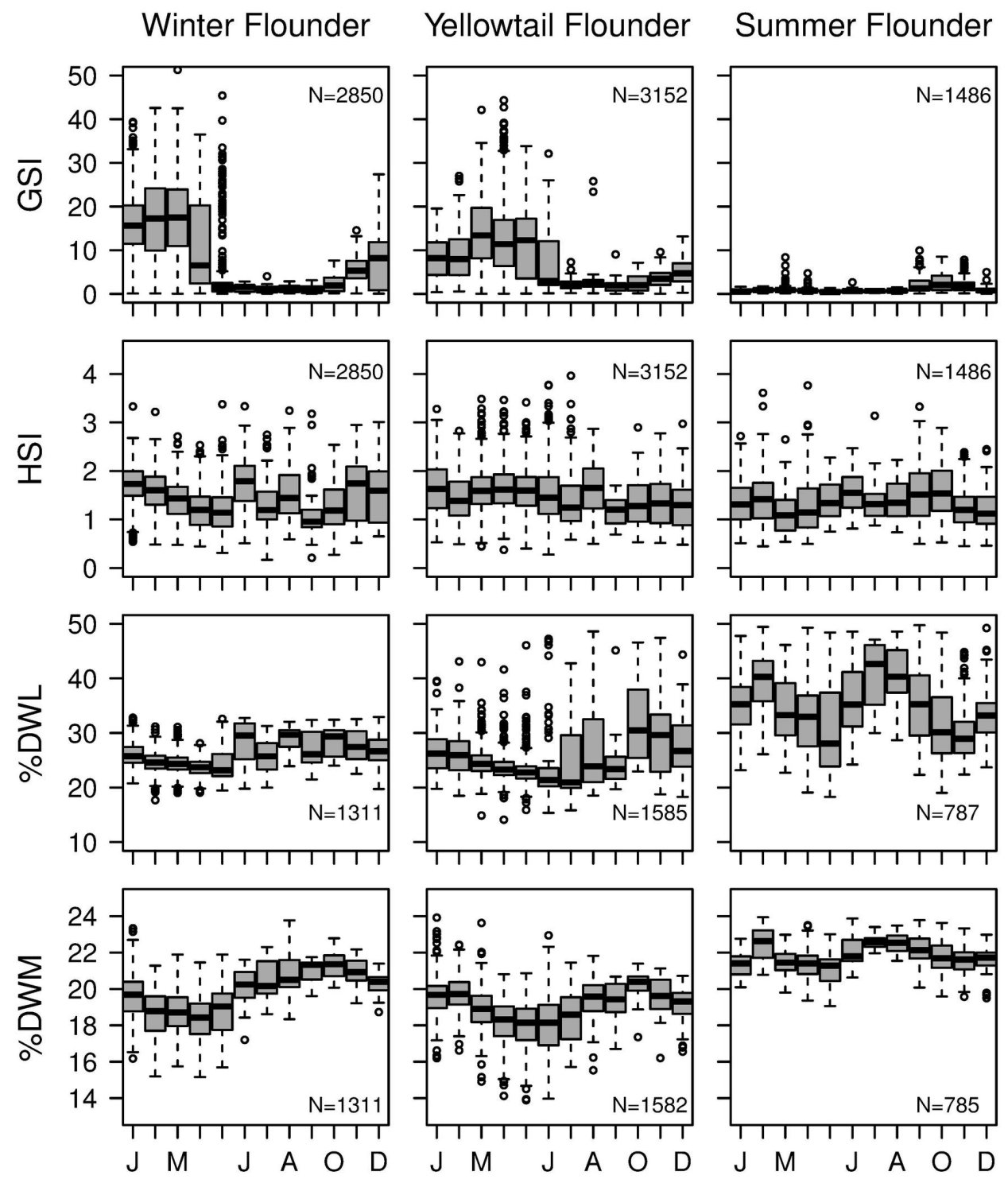

Fig. 2

$157 \times 181 \mathrm{~mm}(300 \times 300$ DPI $)$ 


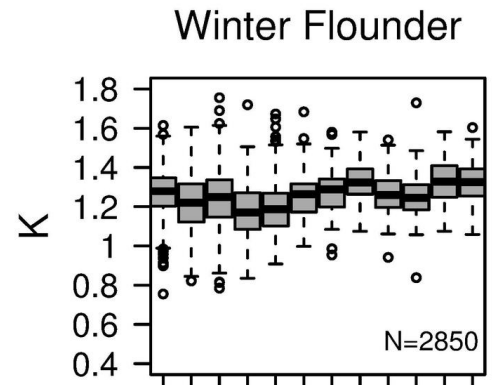

Yellowtail Flounder Summer Flounder
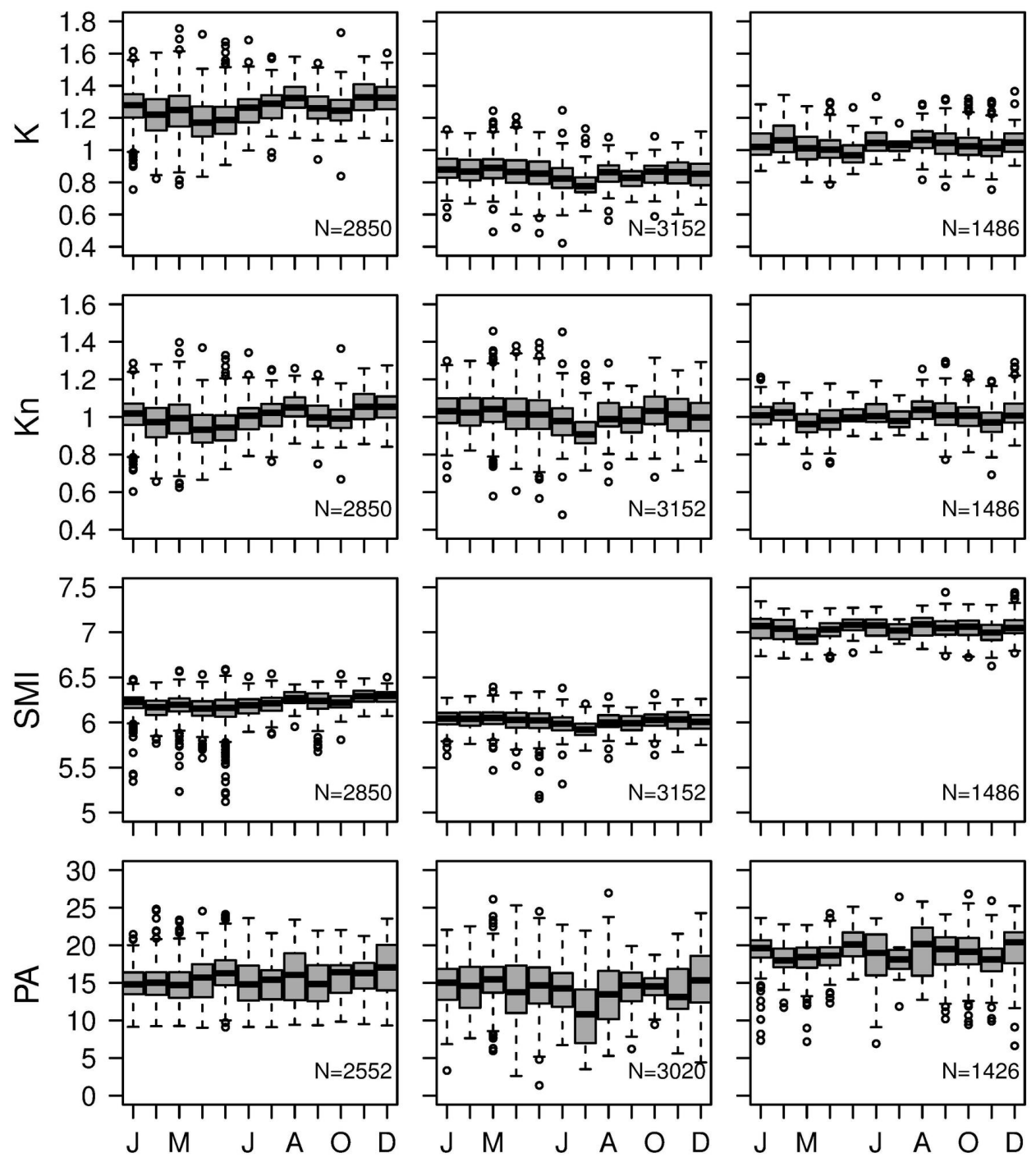

Fig. 3

$157 \times 181 \mathrm{~mm}(300 \times 300$ DPI $)$ 


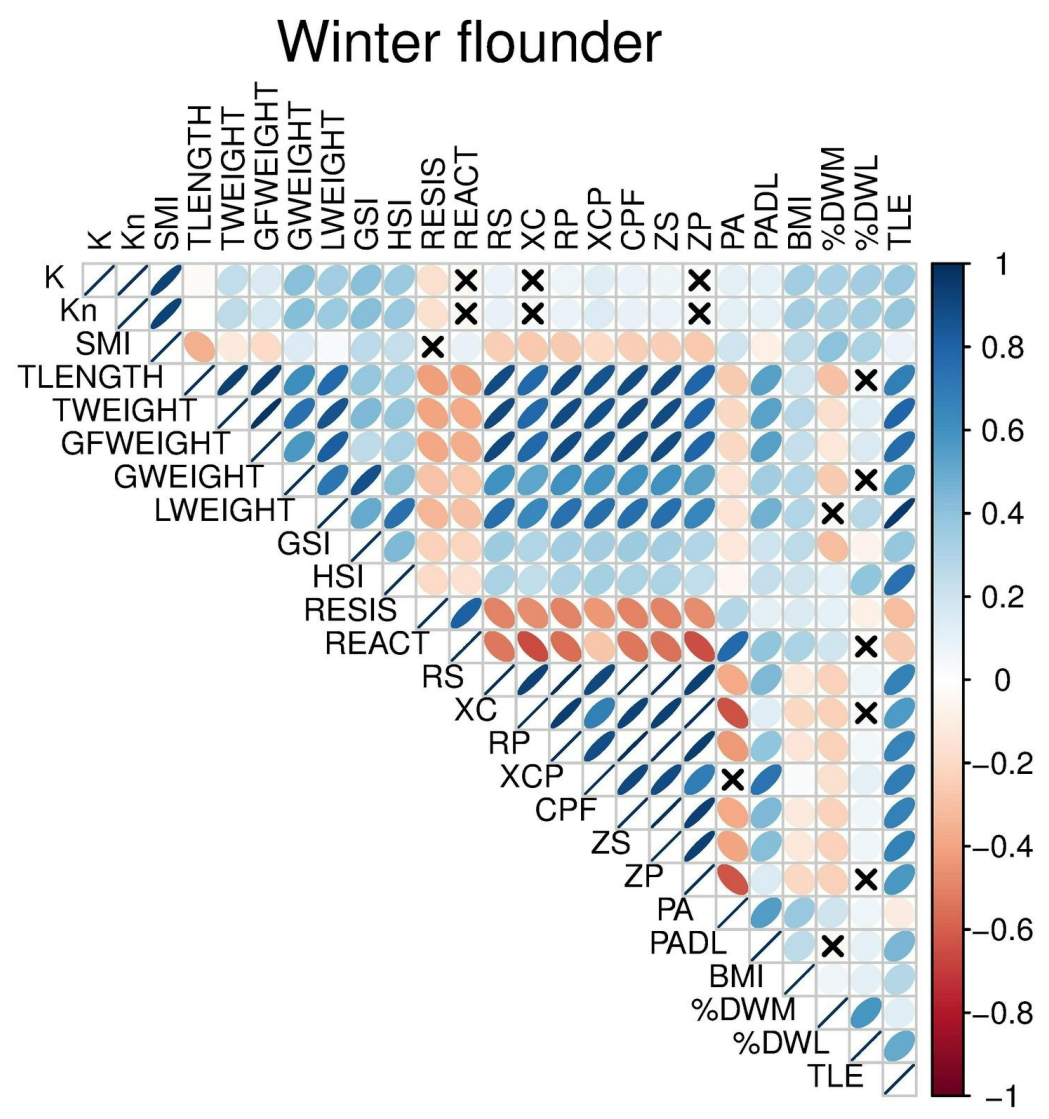

Fig. 4

$157 \times 170 \mathrm{~mm}(300 \times 300 \mathrm{DPI})$ 


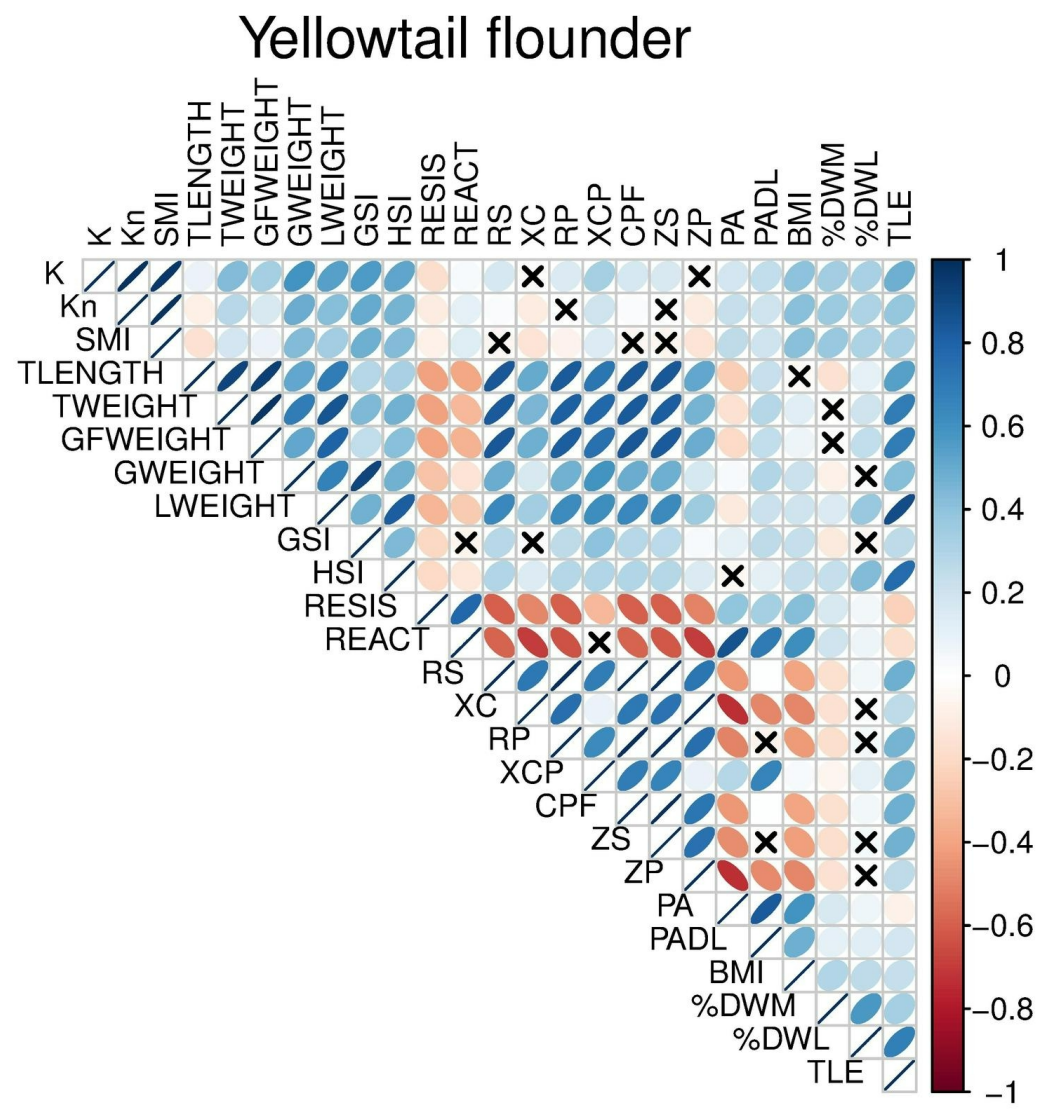

Fig. 5

$157 \times 170 \mathrm{~mm}(300 \times 300$ DPI) 


\section{Summer flounder}

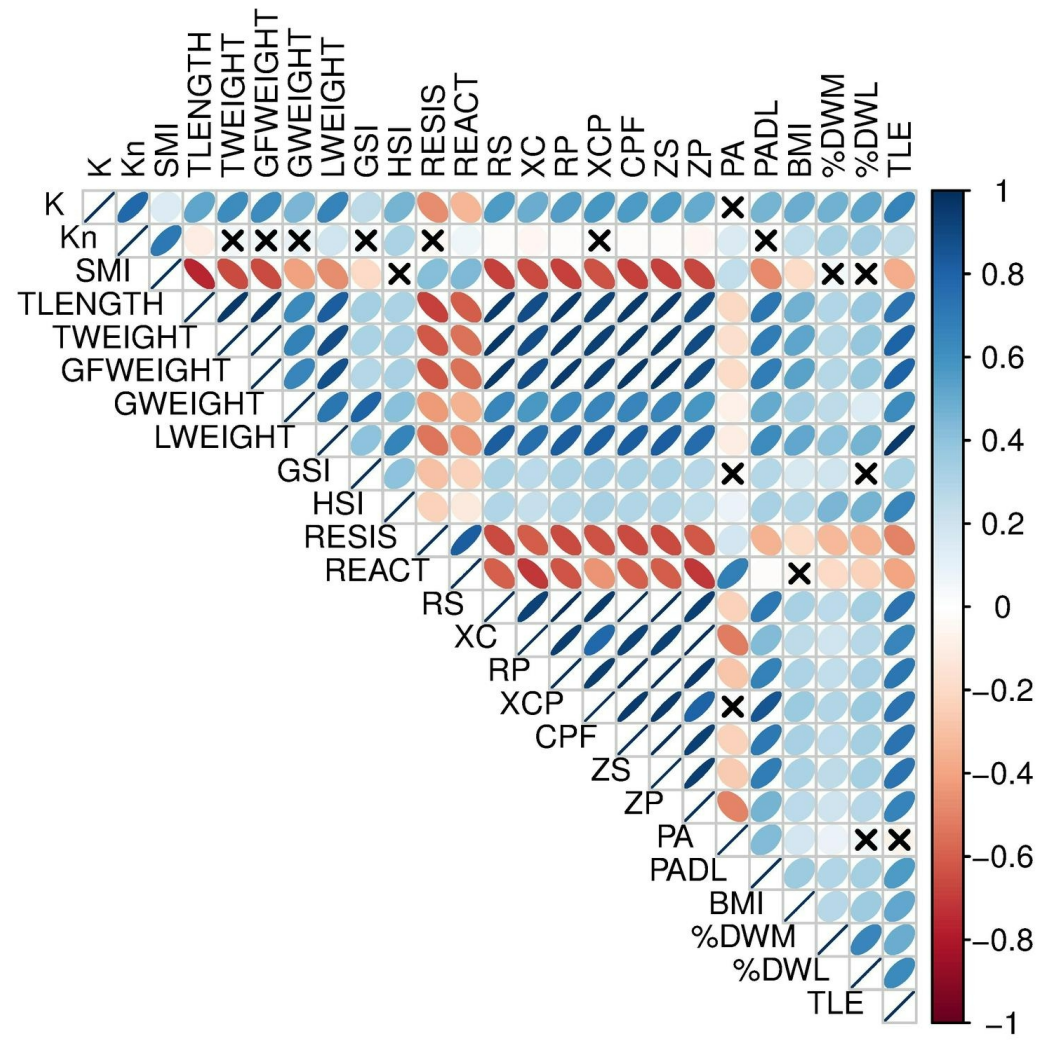

Fig. 6

$157 \times 170 \mathrm{~mm}(300 \times 300 \mathrm{DPI})$ 

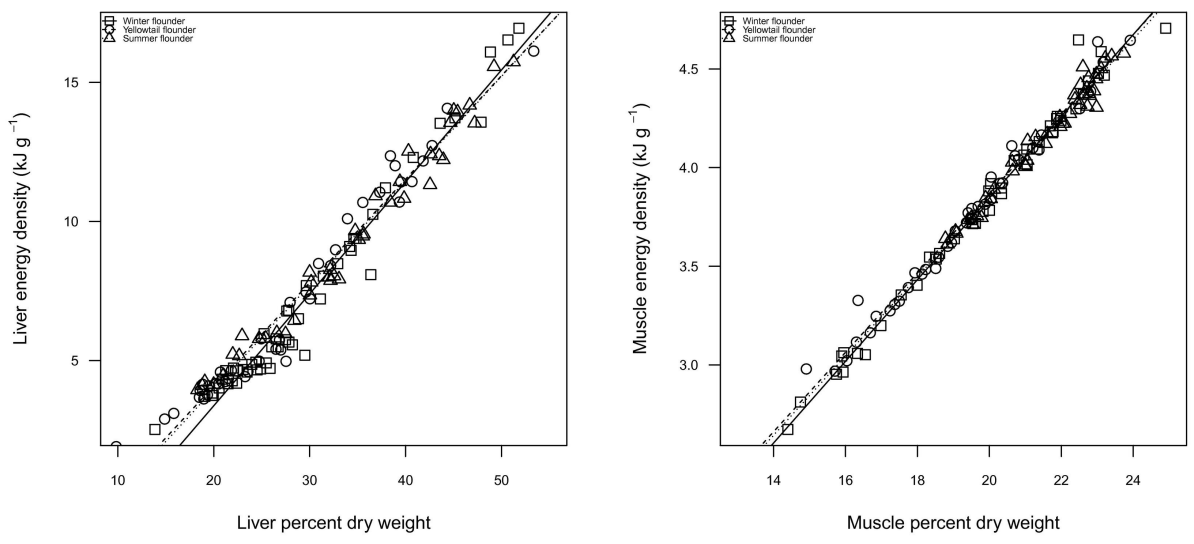

Fig. 7

$301 \times 150 \mathrm{~mm}(300 \times 300$ DPI) 

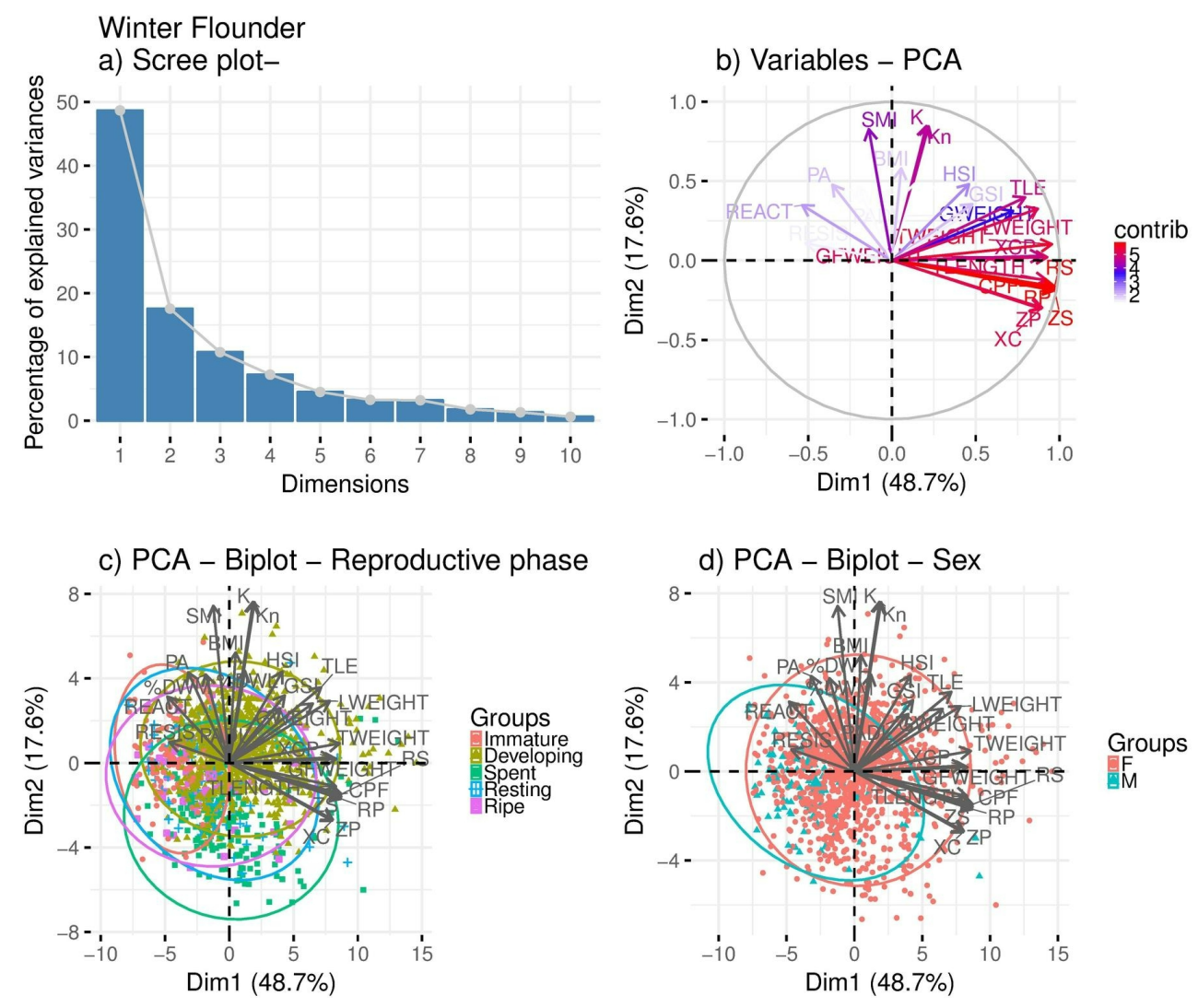

Fig. 8

$157 \times 130 \mathrm{~mm}(300 \times 300$ DPI $)$ 

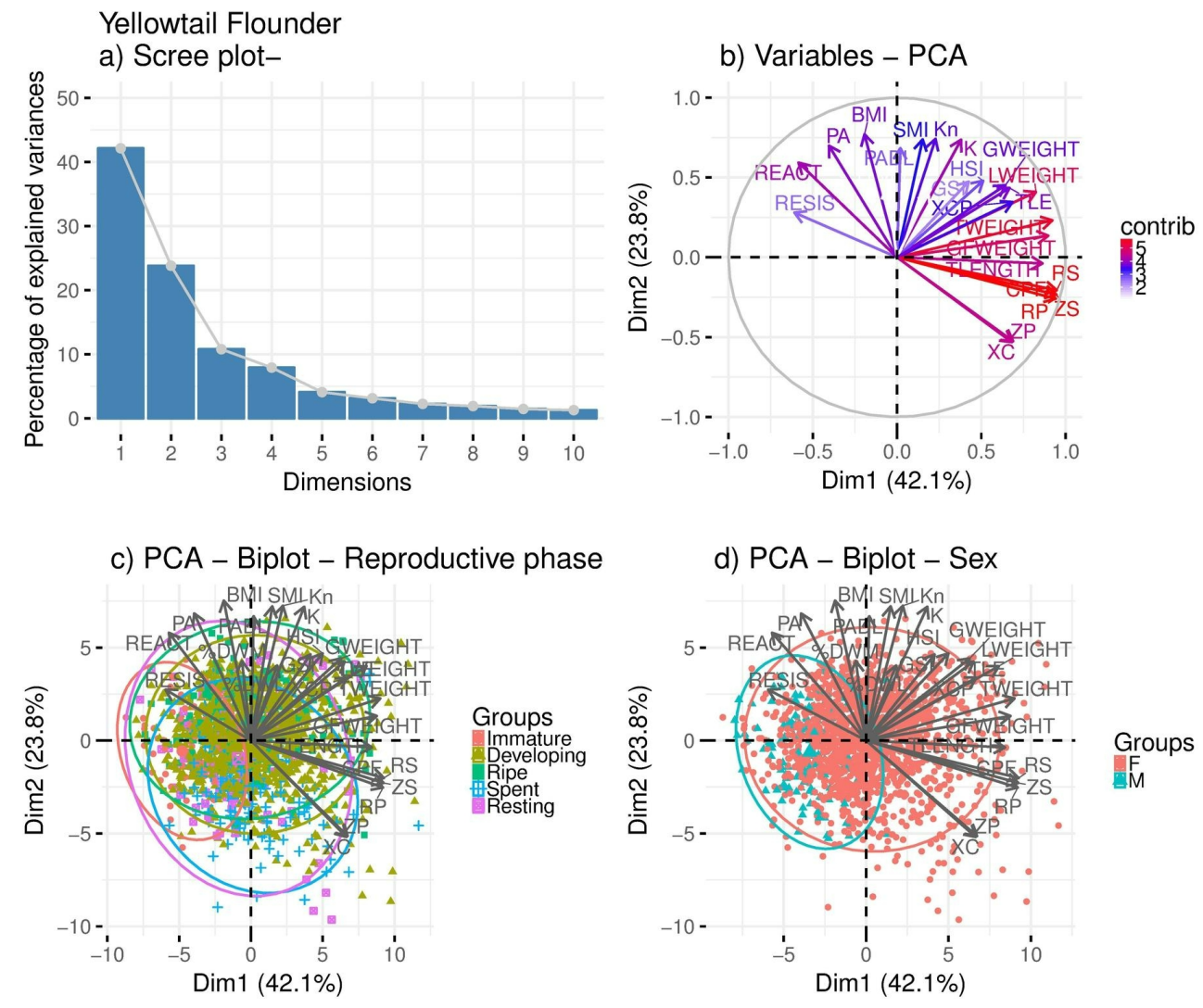

Fig. 9

$157 \times 130 \mathrm{~mm}(300 \times 300$ DPI $)$ 

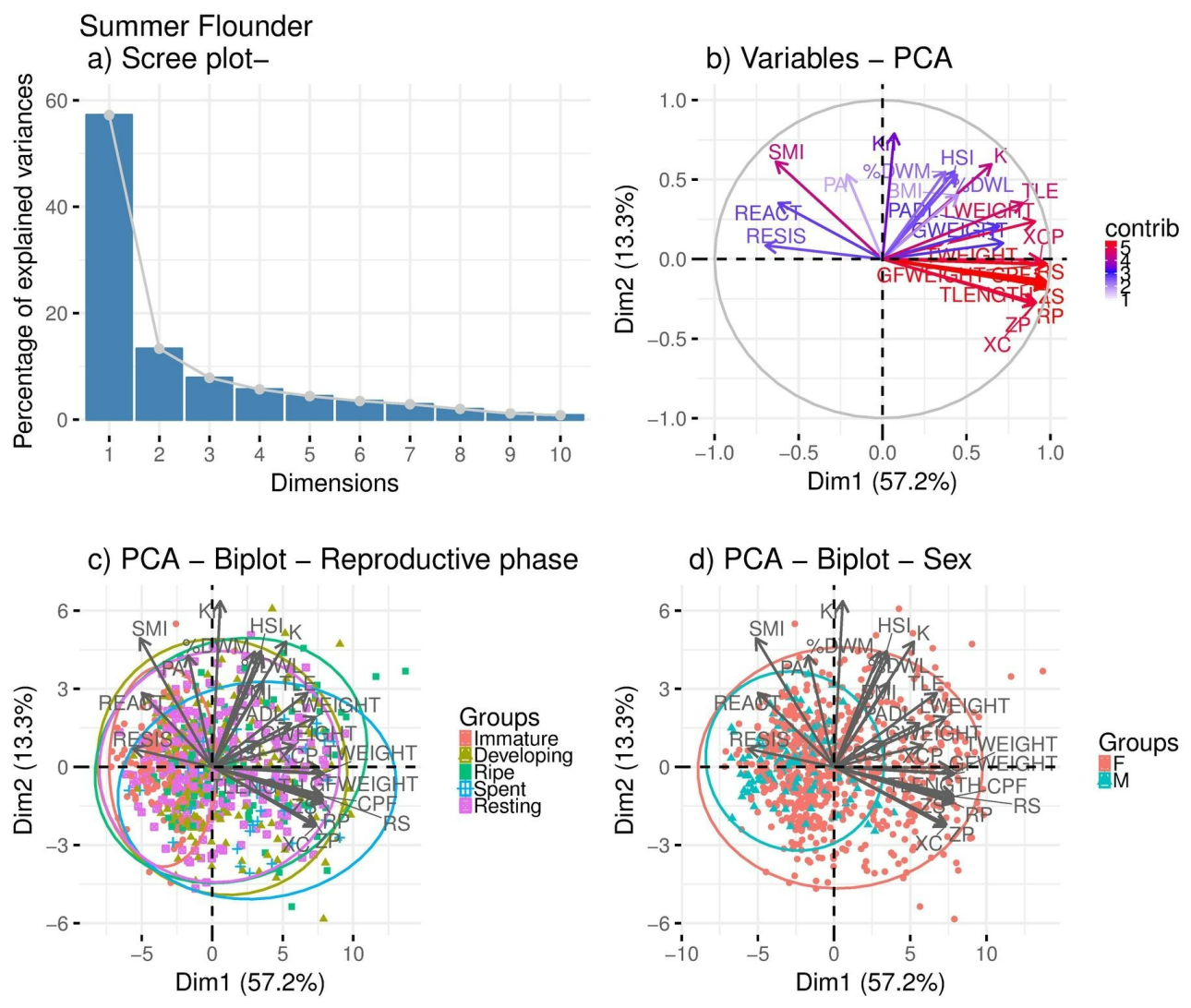

Fig. 10

$157 \times 130 \mathrm{~mm}(300 \times 300$ DPI) 
a) PCA - Biplot - Winter flounder - Stock

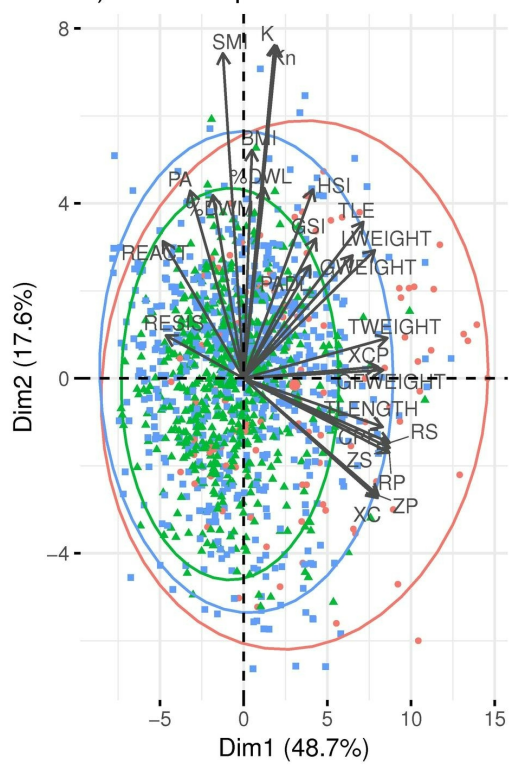

b) PCA - Biplot - Yellowtail flounder - Stoc
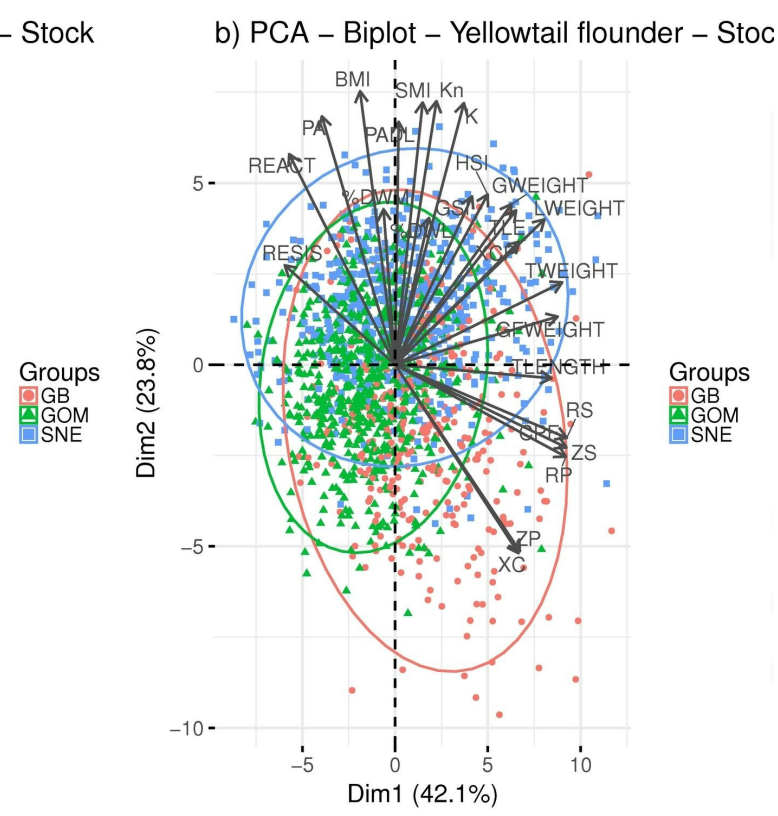

Fig. 11

$203 \times 125 \mathrm{~mm}(300 \times 300$ DPI $)$ 